\title{
The caste - tribe conundrum: Ivory tower bureaucracy and the manufactured controversies
}

\author{
V.S.Ramamurthy ${ }^{1}$ and M.D.Narayanamurthy ${ }^{2}$ \\ ${ }^{1}$ (Section Officer(Retd.), Pre-University Education Department, No 422, $9^{\text {th }}$ A main, Kalyananagar, Bangalore - \\ 560043, Karnataka, India) \\ ${ }^{2}$ (Social Worker, No. 422, $9^{\text {th }}$ A main, Kalyananagar, Bangalore - 560043, India
}

\begin{abstract}
The reservation scheme for Scheduled Castes (SC) and Scheduled Tribes (ST) in India is deficient in terms of the lack of accurate information about each community giving a hand of arbitrariness to a section of bureaucracy who interpret the current lifestyle of some communities and arrive at wrong conclusion. The preconceived notion such as the skin complexion, the stature, the shape of the nose, the food habits and style of worship are being paraded to deny benefit to some communities given by the Indian constitution. An important consequence is that the beneficiaries are subjected to prejudiced enquiries, the threat of arrest, criminal prosecution and dismissal from the job. It is important to remember that a tribe is not deemed to be included in the scheduled tribe list on the basis of the community being a tribe alone but it has to fulfill the requirement of social, educational and economic backwardness. Several communities in the ST list may not fulfill the later day definition of tribes. In this sense many communities have attributes that are hardly conforming to such a definition of 'a tribe'. The need of the hour is a pragmatic approach and a reappraisal of the notions that takes into account the overall development of Indian Society. In order to remove the arbitrariness in defining the characteristics that raises question about the inclusion of certain communities, it is suggested that a new category may be introduced by a reworking of the SC and ST quota.
\end{abstract}

Keywords: Maleru and Maaleru, real and imaginary communities, Scheduled Tribes

\section{INTRODUCTION}

There is a long history for the origin of reservation for SCs and STs in India. Since the 1850s these communities were called as Depressed Classes. After independence the Constituent Assembly continued the prevailing definition of SCs and STs, giving (via articles 341 and 342) the president of India and governors of the states a mandate to compile a full listing of castes and tribes. The complete list of castes and tribes was made via two orders: The Constitution (Scheduled Castes) Order, 1950 and The Constitution (Scheduled Tribes) Order, 1950[1], respectively. Thus the list which was evolved in the 19th century came to be largely accepted as a list that got designated as SC's and ST's post-independence too. Hence, it is inappropriate to arrive at a conclusion on any community by observing their present state of being because the plight of these communities six decades before was a story of suppression and humiliation. Apparently no compendium of details about various communities in reserved list has been maintained by the Government [2]. This may lend an undue hand of arbitrariness to the authorities. It is also true that the communities and individuals may either knowingly or otherwise tend to misinterpret the order because of phonetic similarities. In such a situation where a malpractice is alleged upon an individual of illegal claim of belonging to a scheduled category, the issue lands up in the courts. The courts, in the absence of community wise details, rely upon descriptions that sometimes serve to 'paint with the same brush' leaving certain communities in supreme state of helplessness. Further, the classification of a community as a tribe is riddled with a huge definition deficit. The concept of aboriginal tribes and the efforts to impose such definitions on scheduled tribe communities is fraught with the danger of denying the constitutionally given benefit to some ST communities. The straightjacketing of ST communities into aboriginal tribes is a travesty of truth. Therefore, this article is written with an intention to obtain sufficient clarity on the issue and dispel several myths so that the injustice meted out to some communities due to misinterpretation - either prejudiced or lack of information - by a section of authorities in the Government as well as individuals and communities can be alleviated.

\section{THE PERCEPTION RULES THE ROOST}

The common perception is that while the SC's are those communities which are outside the four Varnas of the Hindu caste system and have to be necessarily untouchable, the ST's are invariably the so called aboriginal tribes living in deep jungles and living a life of barbarism with physical features such as dark complexion, short stature, virtually deformed nose, curly hair and diminutive. Further, in the case of the ST's the hidden definition which is often made explicit is that they exist with a bare covering of their body parts with 
leaves and run away at the very sight of an individual from the normal society. It is possible that this may have been true in the case of a few communities in the 19th century. The application of this extreme definition to all ST's even to this day is an act of extreme exaggeration that has the danger of denying the constitutionally given benefit to some communities who may not have the strength of either the number or the political or economic backing. In this background we take note of the observation of courts regarding the possible ways to verify the claim of a person as belonging to a caste/tribe that qualifies them to be part of SC/ST.

In the case of Patil [3], the Supreme Court observes that "The anthropological moorings and ethnological kinship affirmity gets genetically ingrained in the blood and no one would shake off from the past, in particular, when one is conscious of the need of preserving its relevance to seek the status of Scheduled tribe or Scheduled Caste recognized by the Constitution for their upliftment in the society. The ingrained tribal traits peculiar to each Tribe and anthropological features all the more become relevant when the social status is in acute controversy and needs a decision. The correct projectives furnished in pro forma and the material would lend credence and give an assurance to properly consider the claim of the social status and the concerned officer or authority would get an opportunity to test the claim for social status of particular caste or tribe or tribal community or groups or part of such caste, tribe or tribal community. It or he would reach a satisfactory conclusion on the claimed social status".

With utmost respect to Supreme Court's observation but in the supreme interest of generating clarity, the above cited affirmity test requires the following analysis. Let us look at the observation that "no one would shake off from the past, in particular, when one is conscious of the need of preserving its relevance to seek the status of Scheduled tribe or Scheduled Caste". The purpose of reservation is to help the community to progress. Whether one likes it or not, the progress will obviously ensure a substantial or complete disappearance of the anthropological moorings and ethnological kinship affirmity. But the need to pass the affirmity test in order to enjoy the benefit of reservation especially when one is conscious of the benefit, imposes on the community the impossible task of retaining the requirements of affirmity test while the utilization of reservation pushes them to shake of their past as a concomitant result of progress. Here the extreme contradiction is obvious and clearly unsustainable. Either the tribe or tribal community will continue to live its life with the anthropological moorings and ethnological kinship without utilizing the benefits of reservation or uses reservation and advances but loses the affirmity test.

Manjunatha and Annapurna[4] write that there is no reason to expect or demand that the tribal should either wholly retain or lose all of his culture. It can be argued that only a part of a tribe or tribal community would have used the reservation benefit and hence may not be able to pass the affirmity test while the rest would pass the affirmity test. But that is only an argument. Even if we accept for the sake of argument that a part of the tribe or tribal community would be able to pass the affirmity test, then again a section of bureaucracy who are bent upon creating mischief will invent an argument that the developed section of the community is a different community and hence the reservation benefit is not meant for them. The reservation as well as the generally progressive environment coupled with the welfare measures such as land reform act can be expected to lift the community to a point where it cannot pass the affirmity test. Also if affirmity test should be a 'be all and end all' threshold through which a claimant has to get his claim cleared then the Govt has to evolve such a hard and fast procedure. In the absence of such a rigorous procedure, the effort to impose such restrictions amounts to giving a hand to unscrupulous elements in the bureaucracy for foul play. Further, a revenue authority such as Tahsildar and the Deputy Commissioner with full state machinery such as men, vehicles and allowances at his command can be justifiably expected to have a proper knowledge of the communities living or not living in his jurisdiction. That is the essence of the responsibility of that position. It is only if the authority is interested in enjoying the ivory tower existence and does not acquaint himself/herself about the people whom he/she is required to care, then the individuals from the deprived communities needs to satisfy the authority with paraphernalia of documents such as affidavits to support their claim. Hence, with all humility, it must be stated that there is no escaping the fact that often the affirmity test would be only to the detriment of the deprived sections while there is the danger of it catering to the lethargy and uncaring attitude of the authorities.

There are instances when the authorities prescribe a certain lifestyle to define a community as genitive tribe eligible for certifying them as ST. For example, a controversy has been manufactured by a section of the officialdom in Karnataka in the case of Maleru community. The community by name Maleru has been listed as a Scheduled Tribe in the Constitution (Schedule tribes) order 1950 [1]. The authorities contend that there are two communities of the same name, one the so called genitive tribe Maleru who supposedly live in jungles and even eat roasted hill ants while the other live in villages and towns and are not tribes. The allegation is that the later community has originated from Brahmin community and falsely claiming as Maleru thus cornering the benefits meant for STs [2]. The authorities are now writing the name of the later community as Maaleru. The existing community has been writing its name as Maleru in English since time immemorial, much before the Government introduced the scheme of reservation. This version in English has all along been written as దో๖ృீరు and मालेरु in Kannada and Hindi, respectively as can be verified from the Census records [1][12]. 
Therefore, the effort of the authorities is to force the English version of the name from vernacular. The motive appears to be to deny the benefit to the existing community.

Therefore one should understand the meaning of the term scheduled tribe. The "Scheduled Tribes" is a term used for administrative purposes to confer certain constitutional privileges and protection to a group of people who are considered to be backward and disadvantaged [5]. According to Baxi commission report [6] the stigma of untouchability is the declared criterion for classifying SCs while STs are constituted of those that were subjected to social ostracism and segregation from the general population. In other words, the constitutional order does not require that a community has to be a tribe in the strictest sense to be included in the list of STs. Also, a tribe does not automatically deemed to be an ST unless specifically included in the ST list through the presidential order.

Therefore, in this background we analyze the subject of inclusion of communities in schedule (list). It is pertinent to understand the nature of different communities that are presently in the schedules, say the STs. It is time to ask some questions that will set the agenda for this paper. Whether a community has to live in jungles with 19th century existence even in $21^{\text {st }}$ century to prove that they are the true beneficiaries of reservation? Whether the community should necessarily be non-vegetarian in food habit that includes the consumption of ants, rats, crabs etc. Whether the wearing of sacred thread will compulsorily bar them from being considered as a Scheduled Tribe? Most importantly, should their looks, the stature, the skin complexion etc be necessarily conforming to a determined set? For example, should they be compulsorily dark in complexion, short in stature and compulsorily having broad and deformed nose and curly hair? Should they be animist and have no rituals or deities that are associated with the larger Hindu community? This perception is largely a myth and is manufactured by the opponents of social justice. The essential point to be considered is whether the Indian Constitution and the laws have prescribed these as absolute determining factors to classify a community as ST? The answer is an affirmative no. Therefore, as an example, we discuss the controversy of Maleru community in the ST list with a view to dispel several myths that may help to consolidate the social justice framework.

\section{Pre-Conceived Notions And The Manufactured Controversies}

\subsection{Meaning of the term aboriginal}

Whenever a dispute arises, the Govt tends to view the claims of communities about the genuineness of their inclusion in the ST list on the basis of whether they are aboriginal. Therefore, we first look at the definition of the term aboriginal. The Collins English Dictionary defines the term aboriginal as "existing in a place from the earliest known period; indigenous; autochthonous (Originating where found)", when used as an adjective and "characteristic of the native peoples of Australia when used as an adjective or noun. Random House Kernerman Webster's College Dictionary defines it as "original or earliest known; native; indigenous" and also as "pertaining to the Aborigines of Australia".

\subsection{Antiquity of aboriginity}

Keeping in view the description in 3.1, we coin a new term 'aboriginity' to represent the probability of evolution of a group of humans where they are found presently. Although other phrases such as indigenous, autochthonous etc. may convey the same meaning, the coining of the term 'aboriginity' is absolutely necessary because too much reliance is placed upon the definition of who is an aboriginal as though this is absolutely central to claim Scheduled Tribe status. Such an insistence renders many existing claimants as false beneficiaries. Thus the important point to ponder is whether today we can scientifically establish the aboriginity of any group of humans? In all probability the answer to this question is in the negative. In such a situation it must be borne in mind that the use of terms such as 'aboriginal' to decide whether an X or Y community was the one included in the scheduled tribe list has the danger of being misinterpreted by the bureaucracy. As pointed out earlier, an aboriginal tribe is not deemed to be a scheduled tribe unless specifically included in the ST list. Further, the presidential order neither indicates that all aboriginals are STs nor excludes the so called nonaboriginals from the ST list. In this context, it is pertinent to note that tribal characteristics are obtainable by a group of people on account of isolation - social, geographical and economical, and not necessarily a derivative of aboriginity.

\subsection{Views of the officials driven by the notions-A huge mix up on the definition of tribes}

The tribe is an administrative category in India. The term 'tribe' was introduced in India in the nineteenth century. Most of the definitions equally apply to the castes and tribes. The early writers were unsure of the distinction between the caste and the tribe. They labeled the castes of mixed origin also as tribes. The basic features of the caste and tribal organizations do not differ. And yet, the officials continue to overemphasize the Caste-Tribe dichotomy.

'Forest Tribes' was used as a sub-category under the category of 'Agricultural and Pastoral Castes'. Thereafter the term animist was adopted followed by the term Tribal Religion. The Primitive Tribe was replaced 
by 'Forest Tribe' in 1931 census. Later 'animism' was replaced by the tribal religion. The tribal councils are not the essential features of all the tribes. The disposal of the dead by cremation and burial is practiced by both the tribes and castes. Even Indian scholars have often declared a caste as tribe on flimsy grounds. The caste - tribe continuum is a reality in India. Many communities claim to be the castes and are labeled as tribes. There is a need for a realistic re-appraisal [7].

\subsection{Ethnographic note on Maleru community}

In the case of Maleru community, the Government is in possession of an ethnographic note. The letter by the Ministry of Home affairs [8] says that the traditional occupation of Maleru (Scheduled Tribe community) is that of temple servants. The ethnographic note describes them as "a community of temple servants found chiefly in Malnad region. In Mysore Census Report, it has been mentioned that in some temples of Malnad, there exists a set of females, who though not belonging to the Natuva class, are yet temple servants like them and known by the name Maleru. Any woman who eats the sacrificial rice strewn on the 'balipitam (sacrificial altar)' at once becomes Maleru. The census of Mysore 1911, however recorded the chief occupation of the Malerus as cultivation and labour'. Neither the covering letter nor the ethnographic note writes it as Maaleru. Further, in the previous section (3.3) we see that even the agricultural and pastoral castes have been described as forest tribes. Hence, it is only naturally that the Malerus have been listed both as temple servants and 'Forest and hill' tribes. Elsewhere, we learn that the distinction as towns, villages and hills is spurious in the case of Malnad. Hence, the similarity of the name in both English and Kannada at both the occupational categories explains the fact that they were two groups of the same tribe pursuing diverse vocations contingent upon their predicament. Further, the ethnographic note does not describe them as hunters and fowlers. Hence, terming the Maleru as hunters is without basis. Therefore, there is virtually no reason to even assume that the absence of an ethnographic note is the reason for the controversy. However, the bureaucracy is driven by skewed notions about the nature of STs and hence they are not willing to give credence to the said document. This being the case, it is not impossible to understand the effort being invested to create a controversy except prejudice.

In a significant development, a letter dated 21 October 2013[9] by the Ministry of Tribal affairs, Govt. of India states that the Hindi translation of name Maleru is मालेरु and the same is included in the ST list of Karnataka. In an environment where no prejudice exists, these two documents seen together would amount to terming the controversy as utterly false. However, the reality is different.

It must be noted that the ethnographic note does not specify the language of that community. But from the fact that they were found in Malnad, we can infer that their language could be Kannada. This is important because as described in this article, the authorities have been hammering out that the language of the so called primitive Maleru is Tulu as though a Kannada speaking community cannot be a tribe.

Therefore, in this context, it is meaningful to note the following judgement. This pertains to the Writ Petition of N.Chandrika vs Chairman, Selection Committee [10]. In this instance, N.Chandrika was an applicant for a medical seat in the Government quota in the category of a backward caste by virtue of belonging to Stanika caste which was mentioned in the list of backward classes. The college administration insisted that the reservation to Stanika persons will be available only if they are temple servants. However, the candidate had mentioned her father's occupation as Ayurvedic Physician. Hence, the college declined to give her a seat under the reserved quota. The Hon'ble High Court of Karnataka observed as follows. "This is rather strange. In the Book "Castes and Tribes of Southern India" by E. Thurston, a recognized authority on the subject, 'Stanikas' are said to be very few in number on the date of the writing book. 'Stanikas' are described as persons who claim to be Brahmins but not accepted as such by other Brahmins. They wear the sacred thread. Stanikas are also called as Shanbogs and Mukhtesars. However, it is clarified that Mukhtesars of a temple may be Stanikas. Otherwise, there is no additional information about this caste. This sociological information will not be of much assistance to Selection Committee. What is important is Stanika caste is included in the list of backward castes prepared and published by the Government for the purpose of conferment of benefits under the reservation to be made in furtherance of the mandate of Articles 15 and 16 of the Constitution........In the ancient Varnashrama Dharma system, caste and occupation may go together but it is diluted and degenerated as it exists today. Caste plays no role in determining the occupation."

In the light of this observation, it is obvious that, in the case of Maleru (sic Maaleru) community the authorities have given a go by to such judicial decisions and to circumvent the same, invented the two community theory.

\subsection{The false proposition of the existence of the so called genitive tribe Maleru: An unintended effect of judgments - two community theory}

Instances exist where the authorities refuse to accept the claims of some communities as belonging to a specific reserved category such as ST. This is not about the new inclusion but a claim about the existing entry. 
In the judgment of Smt.Shobha Laxmi W/O Shankara... vs The Divisional Commissioner [11], the Caste Verification Committee has emphasized that the petitioner belongs to Maaleru Brahmin community.

Without going into the merits of the individual's documents, we must note that an unintentional outcome of this judgment is to imply 'judicial sanctity' to the view that two communities with names as Maleru and Maaleru exist. Here, we must remember that, in the 1901 Census [12], a list of 101 sub sects of Brahmins has been mentioned but a group whose name is spelt either as Maaleru or as Maleru finds no mention. At the same time, evidence is available to prove that a community by name Maleru exists whose traditional occupation could have been that of temple servants but presently engaged in labour and marginal agriculture. On the other hand, the Govt have not been able to prove the existence of another so called primitive tribe Maleru who are different from the existing community except cooked up efforts by some vested interests in the Karnataka state bureaucracy and NCST (National Commission for STs). This appears to be an effort to deny the constitutionally given benefit to Maleru (sic Maaleru) by manufacturing a non-existent primitive tribe.

\subsection{The blind approach of the Caste verification Committee}

In the judgement of Shantala G.Rao vs The Divisional Commissioner [13] delivered by the Karnataka High Court, the judgement reads that the 'Appellate Authority referred to the texts on the moorings of the "Maleru" tribals in contradistinction with that of "Maleru" community which has no tribal character but a unique community in Malnad Taluk of Western division consisting of Debrahmanised women of Sacerdotal Class and their progeny attached by the name of "Maleru" to the Shiva temple.' It is also mentioned that "the letter dated $23^{\text {rd }}$ April, 1996 of the Director of Social Welfare, Government of Karnataka stating that the persons belonging to that "Maleru" community who descended from 'Brahmin' caste, cannot be treated as 'Scheduled Tribe' was considered by the Caste verification Committee and was also taken note of by the Appellate Authority."

Again without going into the merits of the individual's documents, it is necessary to point out that the ethnographic note about the Maleru community has been ignored by the authorities. The need was to examine this document together with the Census report. It is unfortunate that they are not willing to give credence to a Government document. They are proceeding from a skewed definition of who can be a Scheduled Tribe. If this trend persists, a day will not be far off when people will stop giving any respect to Govt records because nobody knows when a new set of officials discard the previous document as unworthy of consideration. That will be a sad day for the democracy India.

Though a reference has been made to "the moorings of Maleru tribals", no specific writing has been cited in the judgment in support of the same. But the moot point is that the so called authoritative texts cited in the NCST report [2] are nothing short of misrepresentation as shown in the case of Nanjundayya and Iyer (N\&I)[14] (see sec.9.6). The description by Luiz [15] is a completely different version and those of latter day writers [16] (see sections.9.6 \& 9.7) are yet another distinct version. The last set of writings is a blatant apportioning of the details of Malekudiya community to the supposed Maleru tribals. The 'authoritative texts' are largely an arm-chair job and re-hashing of the texts written by different writers about other communities. In reality, no such primitive Maleru tribe exist other than the Maleru (sic Maaleru). This aspect has been described in detail in sections 3.7, 3.8, 9.3-9.12, 9.15, 9.16-9.18, 9.21, 9.22, X.

Leaving aside the issue of whether any evidence exists that Maleru (sic Maaleru) community has emerged from the Brahmin community which we discuss later in this article, it needs to be pointed out that in Himachal Pradesh, the Brahmins, Rajputs and other high castes of Gaddi and Phangwal tribes [16] are STs. Therefore, the argument that a community whose origin was supposedly from the de-brahmanised persons cannot be a Scheduled Tribe is a conclusion arrived at by the ignorant and prejudiced bureaucracy. It is emerging from a skewed mindset of who can be a Scheduled Tribe. At this point it is pertinent to note that the word 'Brahman' has not prevented the communities such as Daivagna Brahman and Viswa Brahman from being beneficiaries of backward classes in Karnataka. It is also necessary to recall the fact that not only the Stanika are claiming to be Brahimins but also the name of this community is mentioned in the list of Brahmins in the 1901 Census. As described in section 3.4, The Stanika community was the beneficiary of the backward classes.

\subsection{The dispute in the court - an effort to debunk the two community theory.}

Though an exact date regarding the creation of the two community theory cannot be ascertained, the first seed of the same was probably sown by Luiz [15] in a book published in 1963. The officials started denying caste certificates and harassment in the form of enquiries and the threat of arrests followed against those who have obtained jobs on the basis of Caste Certificates. An office memorandum of the Karnataka Govt dated.23 October, 1968[17] says that a civilized community known as Maleyavaru is cornering the benefits meant for Maleru. Hence, in this context, we must note that in the book Castes and Tribes of Southern India, Vol.V, Thurston [18] writes that Maleru (or Maleyavaru) are dancing girls and mostly prostitutes. Therefore, the question that crops up in the mind of any neutral observer is that the Govt should clarify when the Maleyavaru who were leading such a pitiable existence became a "civilized" community. 
It is another matter that the officials have never been able to prove the existence of genitive Maleru in the past. The letter of the D.C. of Shimoga [19] concludes that the so called primitive Maleru have probably become extinct. The letter of D.C. of Chikmagalur [19] says that the Maleru community is found in Western Ghats who are dark in complexion with smudged nose, curly hair and they can be easily identified as tribals. Contesting these claims, the Maleru (sic Maaleru) community approached the Supreme Court questioning the two community theory.

A writ petition No.11894/1985[20] was filed in the Supreme Court. When a resolution did not emerge from the Karnataka administration as expected by the Supreme Court, a new petition No.76/2003 [20] was filed again in the Supreme Court. Then the Supreme Court directed the then National Commission for SCs and STs (NCSCST) to investigate and report the fact. With the bifurcation of the NCSCST into National Commission for SCs (NCSC) and National Commission for STs (NCST), the later took over the task of ascertaining the issue of two communities. As mentioned in the next section, the NCST in an extremely hurried manner held a few meetings with the Karnataka state officials and prepared a report [2] which is just a repetition of the stockin-trade version. The report said that there exist two communities whose name is written similarly in English. In response to the same, the Supreme Court recently (18 April 2013) gave an order giving liberty to the petitioners to assail the NCST report. It is extremely important that in their highest wisdom, the Hon'ble judges of the Supreme Court have desisted from taking the NCST report at its face value and the petitioners have been given a fair opportunity to assail the same [21].

\subsection{NCST's poor record of field work and the wrong conclusion [2]}

As is clear from the previous section, the real task before the NCST was to discover the so called the genitive tribe Maleru, supposed to be the true beneficiaries of the ST benefit. However, their effort 'to gather some basic information' is extremely uninspiring to say the least. Their itinerary is as follows. The NCST team arrived at Shimoga on the afternoon of $22^{\text {nd }}$ January, 2005, held a meeting with the Deputy Commissioner, other officials and some NGO's of that District followed by a meeting with some members of (sic) Maaleru) community. On $23^{\text {rd }}$ January, 2005 they visited the houses of some more (sic) Maaleru families in Thirthahalli Taluk. Later in the day they arrived at Chikmagalur. On $24^{\text {th }}$ January, 2005 they held a meeting with the D.C., officials and NGO's followed by a meeting with the members of the (sic) Maaleru community and also a meeting with the people of so called Maleru/Malaikudi community. Later in the day they visited Alekhan Horatti village and Estate situated about 51 K.M. from Chikmagalur. They returned to Bangalore on $25^{\text {th }}$ January, 2005.

From the above account, it is clear that the NCST have done a field work of just about a day in the form of a visit to a hamlet where Malaikudi are residing. Actually, the need for the NCST to investigate came up only because the State Govt didn't show any inclination to resolve the issue. The State administration had already reported that the so called genitive Maleru are not found in most of the Malnad. The NCST happily gulped this misinformation and took much trouble to prove that the so called Maaleru are not tribals and concluded that two communities exist. The need of the hour is that, the NCST should have gone for an extensive field work through the Malnad extending over a reasonable period of intense trekking to discover the genitive tribe Maleru. However, it is extremely disconcerting to note that, the NCST has held a few meeting with the State officials and paid a pre-determined visit to a hill top and prepared a report to write the obituary of the claims of a community. This gives an impression that they were sure that a primitive Maleru never existed. Instead, they visited the houses of some people said to be belonging to the so called Maaleru community. The traditional occupation of the so called genitive Maleru is supposedly hunting while that of the Maaleru is temple service. A reading of their report quickly reveals that they found no person or group to fit their claim. However they claim that they found 15 families in one place called Alekhan Horatti in Mudigere Taluk of Chikmagalur District who are supposedly the true primitive tribe Maleru. The fact is that the so called Maleru/Malaikudi tribes are neither wandering in the woods half-naked with bows and arrows nor running away at the sight of 'strangers'. They are agriculturists or working in the plantations, covered by the PDS (ration) and their children attending schools. They have been provided with houses by the Government. The claim of the authorities is that the Malaikudi tribe is the Maleru and the caste certificates were earlier issued to them in that name. The authorities contend that when they stopped issuing certificates to Maleru, Maleru/Malaikudi people started obtaining the certificates claiming to be Malaikudi tribe. Hence, this amounts to authorities claiming that Maleru and Malaikudi are the same. But we must note that this is a futile attempt to establish that Malaikudi are also called as Maleru. It must be remembered that Malaikudi are a separate tribe whose name is also found in the ST list of Karnataka as an independent declaration. If Maleru and Malaikudi are two names of the same community, then the conclusion is that the two names are synonymous. In that case two tribes or rather the two names of the same tribe would have been mentioned together in the ST list as a single declaration as is the case for many other communities. However, the names Maleru and Malaikudi are separate entries in the ST list which is why it is obvious that they are not synonymous. It is clear that post 
controversy officials have artificially merged the non-existent tribe Maleru in the Malaikudi tribe. The ulterior motive is clearly attributable to their claim that these are two names of the same community. In reality, Malaikudi are not Maleru and no other primitive tribe by the name Maleru exists other than the Maleru (sic Maaleru). The NCST report is a bundle of contradictions and a bunch of half-truths. It is a faithful repetition of the official line of the argument.

\section{Origin of the Maleru community and its name}

\subsection{Excommunication issues - the probable origin of Maleru (sic Maaleru) community}

The history of this community remained in obscurity because they did not write it themselves but ignorantly allowed others to do so, who could mould it in their favour. It is pertinent to note that no Government record exists that establishes the Brahmin ancestry of the so called Maaleru. For example, no census record of any period indicates the existence of a community by name Maleru or Maaleru as a sub caste of Brahmins. Even the writings of Iyer indicate that the origin of Maleru is from any four traditional castes [22].

The kinds of expulsion from caste look ludicrous from the point of present day world view. Such a method is described here. If a betrothal takes place and before the marriage, the groom dies, then the bride had to live the rest of her life as a widow with absolute celibacy. In an instance when the parents conducted the marriage of such a bride with another groom upon the death of the previously betrothed groom, the whole family was expelled from the caste (Dubois [23]). He has poignantly captured the fate of an outcaste. He writes that "Of all kinds of punishments the hardest and most unbearable for a Hindu is that which cuts him off and expels him from his caste. It renders him, as it were, dead to the world, and leaves him nothing in common with the rest of society. In losing his caste he loses not only his relations and friends, but often his wife and his children, who would rather leave him to his fate than share his disgrace with him. Nobody dare eat with him or even give him a drop of water. If he has marriageable daughters nobody asks them in marriage, and in like manner his sons are refused wives. He has to take it for granted that where ever he goes he will be avoided, pointed at with scorn, and regarded as an outcaste. If after losing caste a Hindu could obtain admission into an inferior caste, his punishment would in some degree be tolerable; but even this humiliating a compensation is denied to him. A simple Sudra with any notions of honour and propriety would never associate or even speak with a Brahmin degraded in this manner. It is necessary, therefore, for an outcaste to seek asylum in the lowest caste of Pariahs if he fail to obtain restoration to his own; or else he is obliged to associate with persons of doubtful caste. There are always people of this kind especially in the quarters inhabited by Europeans; and unhappy is the man who puts trust in them! A caste Hindu is often a thief and bad character, but a Hindu without caste is almost always a rogue. A Hindu, of whatever caste, who has once had the misfortune to be excommunicated, can never altogether get rid of the stain of his disgrace. If he ever gets into trouble his excommunication is always thrown in his teeth. Death would be preferable to an out caste than life in a Hindu society." The Maleru (sic) Maaleru community is supposed to have come into existence as a consequence of excommunication. Thus it is clear that (sic) Maaleru were living an abominable existence.

\subsection{The emergence of two or more groups of Maleru (sic Maaleru)}

The process of excommunication has several cruel features. Some were relegated to temple service with the attendant sexual exploitation. A large number of them ended up as servants in the houses of land lords or as menial labourers where too they were exploited in every possible manner including the sexual exploitation. Obviously, such persons were in the 'forests and hills' of Malnad as the residences of their masters was set amidst the thick jungle. That is the typical Malnad. Some were abandoned in the woods albeit temporarily by tying a black cloth around their eyes. Hence, two or more groups, namely, the temple servants, village group etc. emerged. In course of time they merged together to evolve the present Maleru (sic Maaleru). This is a classic case of home coming similar to the process of consolidation seen among other communities too. These hapless beings had no alternative but to forge a group as they were shunned by the established castes. The village group was characterized as forest group by the enumerators who were probably hailing from the plains ignorant of the realities of Malnad. As described in section 9.4, the distinction as towns and forests is totally inappropriate in the case of Malnad.

\subsection{The origin of Maleru (sic) Maaleru community as described in the NCST report [2]}

A brief summary of the origin of (sic) Maaleru community as gathered by the NCST is as follows. "In the olden days, a system had existed wherein the brahmin families used to dedicate the girls to the service of God which renders them to eke out a living on their own ensuring a miserable existence, mostly in temples. There was also a practice of child marriage, often to elderly men. Consequently, early widowhood is often the case whose vulnerability was misused by male members of the husband's family or servants or neighbour. According to another source, Brahmins used to have servants from different castes/tribes. In the case of death of 
the male servants, their women were sexually exploited by the men in the master's family". Implication is that these hapless beings and the offspring of such unfortunate liaisons end up as Maleru (sic Maaleru).

It is strange that a community with such a hapless origin, especially emerging out of the tribes as mentioned in the NCST report itself, are not considered as tribes but artificially upgraded as Brahmins by the NCST even when the Brahmins and even other castes look at such beings with utter scorn. This can be best understood if one looks at the fact that a Hindu upon conversion to another religion will no longer be called a Hindu.

\subsection{The probable origin of the name Maleru and its artificial alteration as Maaleru}

No document exists that has recorded the emergence of the name Maleru. However, there are a few versions regarding its origin. One version which is mentioned in the NCST report is that a group of people who were primarily engaged in making garlands or 'Male (దో๖ి)' to local deities came to be known as Maleyavaru [2]. This has purportedly led to the name Maleru (sic Maaleru). The officials argue that in contrast, the meaning of the word Maleru is to indicate that they are a community of 'Male' or hills which supposedly lead to the so called genitive tribe name Maleru. On this basis they contend that (sic) Maaleru are not tribals, terming them as certain caste people leading normal life in towns and cities that belong to the high caste society [17]. Their intention is to infer that the word Maleyavaru is transformable only as Maaleru. But they conveniently ignore that the word Maleyavaru can also mean as persons belonging to hills. The difference is in the way the letter 'a' after ' $\mathrm{M}$ ' is pronounced. It is pitiable that the officials do not realize that in both the words, the letter ' $\mathrm{a}$ ' after the letter ' $M$ ' should be either a short vowel or a long vowel and it cannot be twisted according to their convenience. In other words, if ' $a$ ' is used as a short vowel in both the words, it can mean as 'people from hills' $($ Maleyavaru $=$ Maleru) and if 'a' is used as long vowel, it can mean as 'people making garlands' $($ Maleyavaru = Maleru (sic) Maaleru). The meaning cannot be selectively implied according to the prejudice.

Another version is also described in the NCST report [2]. They have taken great pains to interview a few persons who purportedly gave the interpretation that the name Maaleru has originated from the word 'Maleenaru' supposed to mean the 'impure or polluted' due to the peculiar origin of this community. This is another instance of reckless mistake in the way the Kannada word is pronounced and spelt in English. The right way is to pronounce and write it is as 'Malinaru' in which the letter 'a' after ' $\mathrm{M}$ ' is a short vowel. The letters 'ee' after the letter ' $\mathrm{l}$ ' is an improper use as it distorts the Kannada word. Another Kannada word conveying the same meaning is 'Kalushitharu', where too the letter ' $a$ ' after ' $\mathrm{K}$ ' is a short vowel. Then, this word accurately conveys the meaning of 'impure or polluted'. It should be noted that a proper transformation of the word 'Malinaru' can only be Maleru and not Maaleru since the letter 'a' is short vowel whereas in Maaleru, the usage of 'aa' is to force the long vowel. Therefore, the word Malinaru can never get transformed as Maaleru. The authorities have failed to grasp the point that on this basis too, the name Maleru (దులోలరు) with short vowel 'a' denotes the temple servant community and not the so called genitive Maleru. This is a straight forward case of authorities contradicting themselves

There is no way to suggest that, from the beginning the name was spelt with deergha for ' $a$ ',

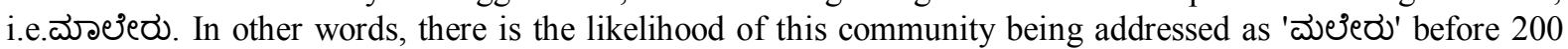
years as can be implied from the probable transformation of the word Malinaru to these people. It is quite possible that over time it got transformed to the form with deergha for 'a' i.e. దో๖ృిలు. The people and caste names are not static. The word Shresti was supposedly the earlier name of the business community and it is said that the same got transformed as Shet, Shetty and Setty.

We must realize that, a correct meaning of place or caste names cannot often be derived because the transformation over time renders them to unpredictable forms. Hence, the logical and legal method to arrive at an accurate conclusion from a seemingly contradictory argument is as follows. In none of the Census, the word Maaleru in English and దుల่లరు in Kannada has been mentioned. In the Census [12] where Maleru is listed under both the 'temple servants' and 'Animist-Forest and Hills', there is no difference in the use of diacritic and also in the Kannada spelling. Therefore, the versions 'Maaleru' and 'డులోఁరు' are certainly an afterthought and 'Maleru and దోతిలరు' are the only correct versions, in English and Kannada, respectively. The Govt and NCST have concluded that the primitive Maleru are not living in either Shimoga or Chikmagalur Districts [19][2] except for the Malaikudi whom they wrongly interpret as Maleru. On the other hand Maleru (sic Maaleru) can prove their existence from about a century in terms of the mention in revenue records and school, college admission extracts and the letters issued by MLAs, local bodies and also the DSS which are identical to the Census record. Except for the writings of the colonial period, the caste names in Kannada or from any Indian language spelt in English have never made a difference between the word with and without deergha. No word with the deergha from the vernacular has ever been written in English with 'aa' to denote the long vowel. Further, as elaborated elsewhere, the distinction as 'villages and towns' and 'Forests and Hills' is spurious in the 
context of Malnad. Hence, the proper conclusion is that the word Maleru in English conveys the word మోఠతిలరు and मालेरु, in Kannada and Hindi, respectively. This is the same as in Presidential Order (STs) Order, 1950[1]. Most importantly when a community's name is never written either by that community or by early census authorities as 'Maaleru', the present effort to write as such is to commence a style with ulterior motives of denying the constitutionally given benefit and hence deserves strong repudiation. This is especially important because benefits are denied by the authorities even if there is a spelling mistake of a single alphabet and the courts too have reaffirmed in more than one judgment the sanctity of spelling of a caste/tribe name as written in the presidential order. Hence authorities must desist from writing the caste name of Maleru as Maaleru. Therefore, if the Govt version should be accepted, then the Govt should start writing the word 'Caste' as 'Caaste' and Mādiga [12] as Maadiga.

\subsection{Reference to Maleru (sic Maaleru) community in Kannada Literature [24]}

Kannada Sahitya Parishat (KSP) has mentioned a tribe by name mAlEru. Here the capital A and E without any doubt represent the long vowel. This style of writing mAlEru can easily be comprehended as corresponding to దోతిలరు described by N\&I (Mālēru) [14] and Thurston (Malēru) [18] concerning the temple servant Maleru. It is significant that KSP have not mentioned the existence of a tribe whose name is supposedly written as దుల่లరు. Dr.Chennanna Valikar the famous Kannada writer has in his monumental work on devadasis (servants of God) mentioned the name దోఠృలరు along with Natuva, Parivara, Bestha, Madar, Holeya, Dombara, Dasa, Devadiga, Devanga, Deevaru, Jatti, Lambani and Mogaveera. His work being in Kannada, he has written the names of all the communities in Kannada. He has written in Kannada as దోతాలతు which corresponds to the temple servants. His entire work is to bring to fore the highly despicable condition of these communities who have been subjected to social ostracization and economic deprivation which abundantly qualifies them to be the beneficiaries of positive discrimination such as reservation. Hence the natural conclusion is that the genitive tribe Maleru is only an imaginary community manufactured by the vested interests in the Karnataka bureaucracy.

\section{Definition Deficit}

\subsection{The lack of definition in the Constitution and the criteria followed for resolving the controversies}

Some attributes are often used to distinguish the tribes. (a) Indications of primitive traits (b) Distinctive culture (c) Geographical isolation (d) Shyness of contact with the community at large (e) Backwardness [25]. It is significant that even when these criterions are mentioned by the authorities, the Constitution of India has not spelled out any criteria. Therefore, the above mentioned criteria can only be a set of guideline in the nature of an advice and cannot be taken as the be all and end all qualities without which a community cannot be accepted as a scheduled tribe. In other words rigidly following such definitions without the application of mind to the existing communities in the ST list will lead to creation of controversies. This highlights the dichotomy of castetribe conundrum. From the above cited ethnographic note, we can understand that the Maleru (sic) Maaleru community was essentially a creature of a system of excommunication that existed long before. A reading of the works of Thurston, Iyer and others reveal that the evolution of many lower castes and tribes was a consequence of a process of socio-economical-geographical isolation as a result of excommunication and segregation. This is also evident from some illustrations in this article.

Being an excommunicated group, Maleru (sic Maaleru) community abundantly satisfied all the five criteria as described here: (a) Indications of primitive traits: They will naturally be at a loss as to the customs they need to follow. Certainly, they cannot continue to observe the customs of their parent community. They will be in a state of search for a new set of customs which will automatically result in exhibiting primitive traits. Anyway, nobody can provide a hard and fast definition of what constitutes the primitive traits. What is a primitive trait to one community can easily be an advanced trait to another community. (b) Distinctive culture: A group that has lost the culture of its parent community can have either a distinctive culture or an admixture of cultures due the compulsion of interaction with disparate groups or no culture at all. Here the word culture is used in the sense of worship, rituals etc. (c) Geographical isolation: In the Indian context, even the lowest caste with even a remote sense of caste pride will not associate with them and hence the most obvious result is the geographic isolation. This and the next criteria can be properly understood if one carefully reads the account of Abbe Dubois cited elsewhere in this article. (d) Shyness of contact with the community at large: Shunned by all castes they will naturally be acutely apprehensive of the larger society and hence the shyness of contact is selfevident. (e) Backwardness: With no rights of inheritance of property and no opportunity to involve in any trade, they will obviously degenerate into an absolute state of socio-economic backwardness. An ugly consequence of the excommunication is that they had to live outside the village or town (Dubois) [23]. This amounts to relegating this community as an untouchable caste/tribe. Here the most important consideration to be borne in 
mind is that one has to look at the situation as prevailing before 1950 and not the fairly better of conditions of 1970 s or later.

\section{Examples of communities in the ST list not conforming to the notions [26]}

We present relevant information about some ST communities to demonstrate the hollowness of the emphasis on aborginity, affirmity test and the prejudices on physical features, geographical, social, economic and educational status, the food habits, the wearing of sacred thread etc.

The Malai Arayans claim that they have an Aryan ancestry. They are mostly very fair and their women quite pretty. By 1930's Malai Arayans gave up animism and ever since, their profession and practice of faith have been similar to those of other Hindus. They had been traditional agriculturists, each family holding hundreds of acres of land. At a time when a majority of the caste Hindus and their Christian counterparts dwelled in mud huts, the Malai Arayans enjoyed the comfort of wooden houses and their couple had a separate nuptial chamber. They never stooped to be agricultural labourers. That they never killed the ant testifies their environmental consciousness. They now style themselves as 'Karinkal Brahmins.' According to a legend, they became tribals by virtue of being banished to forests on account of a gory carnage they witnessed.

The Brokpa tribe of $\mathrm{J} \& \mathrm{~K}$ are said to be purely an Aryan tribe with full vegetarian food habit and do not consume even milk or milk products. They have the looks of Germans.

Gujjars of $\mathrm{J} \& \mathrm{~K}$ and Himachal Pradesh have probably originated from white Huns and they claim descent from Suryavanshi Kshatriyas (Sun Dynasty) and connect themselves with the Hindu deity Rama. Bakarwal apparently have the same origin as Gujjars. In Gujarat, Madhya Pradesh and Rajasthan Gujjars are $\mathrm{OBC}$. Hence, it is clear that the status as to whether they are ST or OBC or general depends on the local conditions.

This holds well in the case of tribes of Himachal Pradesh who belong to the famous Indo Aryan family group. As far as the physical appearances are concerned, these tribes of Himachal Pradesh also have got identifiable features of that of an Indo-Aryan or Mongoloid. The major tribes of this region include Kinnaura tribe, Lahaule tribe, Gaddi tribe, Gujjar tribe. These tribes of Himachal Pradesh have taken up the occupations including rearing of cattle and sheep and produce wool. There are quite a handful of tribes of Himachal Pradesh who have adapted to occupations like cultivation including horticulture.

Some tribes proudly connect themselves to some famous dynasty of kings. Bots are one such community. It is believed that Bot people are Raghuvanshi Rajput. They prefer to be called as Thakurs or Rajwanshi.

Malis are predominantly found in tribal areas of Visakhapatnam, Vizianagaram and Srikakulam districts. The Bodo Malis are considered a superior sect and both men and women of this group wear sacred thread. Their traditional occupation was growing flowers plants and making garlands. But now they are settled agriculturists. They bury their dead and observe ten days of pollution and on the tenth day an Oriya Brahman purifies the house by raising the sacred fire. It should be noted that the letter 'a' has a diacritic in the word Māli but in the ST list it is written as Mali.

The Todas of Karnataka and Tamilnadu are vegetarians and do not eat meat, eggs which can hatch and fish but some villagers eat fish. The forced interaction with civilization has caused a lot of changes in the lifestyle of Todas. The Todas used to be a pastoral people but are now increasingly venturing into agriculture and other occupations. The Toda are considered a group of the Proto-Aryans. They are tall-statured, long headed people with a narrow nose and their physical features conform to the Mediterranean type.

The Gonds are a scheduled caste in Uttar Pradesh and scheduled tribe in Madhya Pradesh. The Khatulwar Gonds have adopted many Hindu customs. They wear the sacred thread of the twice born castes, use the title Thakur. From the book 'The Scheduled Tribes', we learn that, the Karnataka Gonds speak Kannada at home and use the same script. They follow Hinduism and their deities are Venkateswara, Manjunath, Marikamba, Durga Parameshwari and celebrate Ugadi, Dussehra, Diwali, Shivaratri and Tulasi Puja. They accept water and cooked food from the Brahman alone. From the book 'People of India', we learn that Gonds are occasional non-vegetarians, but do not eat pork or beef. The symbol of married women is the earring, nose-ring, nose-stud, toe-ring and thali. The pilgrimage centre for the community is Tirupati.

Gowdalu in Chikmagalur and Shimoga districts in Karnataka consider themselves as higher to Hasala, Muger, Adi Karnataka, Adi Dravida etc. and do not accept cooked food from them. They are traditionally allowed into temples such as in Kalasa and Horanadu. The dead are cremated. Excommunication was resorted to in the past only in the case of adultery. Venkataramana is the community deity of the Gowdalu. There are a few doctors, engineers and teachers in the community.

A Gujjar Bakarwal Kafila when pasturing in Himachal Pradesh during the summer belongs to the scheduled category, the same group loses this status in its winter pastures on the Jammu plains. 
The Barmans of Cachar (Assam) are plain tribes and lived in Barak Valley. It is believed that Barmans are those Dimasas who considered themselves to be descendants of Bhīma, the second Pandava of Mahabharata, and follow Hindu religious principles and wear sacred threads like Kshatriyas.

Bedia community is listed as SC in many states like Madhya Pradesh. However, due to the system of Bedia women forming alliance with higher caste men, they claim the caste of their children as that of some upper caste. However, that does not prevent them from claiming SC status.

Rajbanshis (SC) consider themselves to be Hindu Kshatriyas. They do not eat together with low caste people and Muslims. Lord Shiv is the supreme deity. The people of this community generally have the features mixed up with all four human streams or cultures i.e. Austral-Asiatic or 'Adivasi', Mongoloid and Aryan. From 1890 s, the influence of Sanskritisation could be clearly seen and there was an effort to characterize the Rajbangshis as Vratya (fallen) Kshatriyas. At the same time, from 1912 onwards the Rajbangshi elite organized a series of mass thread wearing ceremonies in order to boost their Kshatriya status. Traditional Rajbanshis are settled agriculturists. Nalini Ranjan Ray is of the opinion that eminent scholar K.S.Singh in his work 'The Scheduled Caste', published by Oxford India Paperbacks, New Delhi, 1993 has given an inconsistent, mixed up information about the Rajbanshis of North Bengal, Assam, Bihar and their adjacent regions.

Devendrakulathans (SC) are said to be descendants of famous ancient Tamil kings Cheras, Cholas, Pandyas and Pallavas who ruled the current Tamilnadu. They are also the priests in village Temples, exclusively owned by these people. In ancient temples like Perur, Samayaburam, Tirunelvelli and so on, leaders of this community are brought to the Temple with festivities on Elephant with white Umbrella coverage, playing trumpets and drums and given the first respect during Temple festivals and are asked to touch the Temple Caravan first before it comes on procession.

According to one tradition, Kaniyans (in Karnataka, Tamilnadu as Kaniyan and Kanyan, in Kerala as Kanikaran,Kanikkar) are Brahman astrologers who gradually lost their position as their predictions became less and less accurate.

Adiyans were subjected to suppression similar to slaves but they are not a geographically isolated community. Yet they are considered as a scheduled tribe (Kerala, Karnataka and Tamilnadu) which would have been appropriate to classify as a scheduled caste. According to one legend, "they are the descendants of the union of a Sivadwaja Brahmin with a non-Brahmin girl". Another legend is that they are a progeny of a Brahmin who lost his status by eating rice offered to Siva and thereby committed an 'anacharam' (violation of a restricted custom).

Goa and neighbouring Sindhudurg and Uttar Kannada had a system of temple-artists called as Bandi. It is said that the widows of Marathas and sometimes even other castes sought shelter in the temples as they were forced to follow the Sati tradition. Bandi is a Scheduled Caste in Karnataka.

\section{The effect of real or claimed origin of communities from the Brahmin community and also the effect of interaction with Brahmins}

We have already seen that several communities that are classified as ST are claiming to be originating from Brahmin or Dvija (Dvija is the common term that represents Brahmins, Kshatriyas and the Vaishyas) community or there is an attempt to upgrade themselves as Brahmins or Kshatriyas. Conscious of such aspects, the framers of the constitution have not imposed any restriction that certain communities which may claim their origin from Brahmin or any Dvija community to claim the benefit of reservation as long as such communities have suffered social ostracization and economic degradation. Therefore, it is unfortunate that there are instances such as the Maleru issue when authorities have brought the issue of Brahmin origin to deny the constitutionally given benefit to certain communities. It is obvious that, many communities are of mixed descent with a large contribution from the upper castes but their claim to belonging to reserved category is not affected. Justice is done to these communities by giving them the benefit of reservation because, in spite of a mixed descent, the offspring are subjected to social and economic deprivation and in an era where reservation is provided for the upliftment of the deprived, such groups must be legitimately the beneficiaries of the same.

VIII. The controversy of Dhangar versus Dhangad[27]

The manufactured controversy in the case of Maleru community appears similar to the issue of Dhangar and Dhangad. Therefore, we can see that the Hon'ble Supreme Court have referred both the issues to the erstwhile National commission for SCs and Tribes in the same order. There is a claim that Dhangar and Dhangad are the same and both refer to shepherd community. Here the controversy could be a case of a difference in one alphabet at the end. There is a claim that several rulers such as Holkars of Indore, Hakkaraya and Bukkaraya of Vijayanagar, the Hoysalas, Rashtrakutas, Maurya, Pallav were all Dhangars. It claims that Dhangad and Dhangar are the same. It also claims that the "Ain-u-Akbari" describes them as being a proud, refractory and domineering race of Rajputs. National Commission for SCs (NCSC) report says that after an enquiry in only Mathura and Agra districts of UP, they concluded that only Dhangar community exists and a 
community by name Dhangad do not exist and hence SC certificate shall be issued only to the members of Dhangar community (Minutes of 29th Meeting of NCSC). Here the issue is in most of the North Indian languages, the letter ' $r$ ' is used in writing whereas the same is pronounced as ' $d$ '. For example, the Surname Chopra is pronounced as Chopda. It is easy to imagine the plight of those innocent Dhangars/Dhangads whose community is written as Dhangad/Dhangar due to the regional peculiarity.

\subsection{The issue of occupation}

\section{A host of objections by the NCST and the answers thereof}

A few remarks by the NCST about the Maleru (sic Maaleru) are as follows. "The Maaleru are of sacerdotal class. They are living in villages and towns and their main occupation is agriculture. They follow Hindu Brahmin system of having single wife. They have physical structure like any civilized person in India whereas the primitive Maleru still have physical structure as specified in the Constitution of India. There is no system of inter caste marriage amongst Maaleru and they are marrying among the Brahmins" [2].

While it is futile to answer such ludicrous remarks, it is necessary to direct our attention to a few related aspects. The communities such as the Malai Arayans of Kerala are also of sacerdotal class. They have also been land lords with a clear opposition to carry load on the head. The Malis are settled agriculturists. There are many such examples. But we must know that the constitutional order do not provide for such an exclusion class that prevents such groups being considered as STs. Further, the whole country is curious to know since when other communities have adopted the system of inter caste marriage? If that were so, by now, the caste system in India would have vanished. Isolated cases of love marriage with Brahmins are being blown out of proportion. There have been a few marriages by Maleru (sic Maaleru) persons across the entire spectrum of castes on account of love affairs. In the year 2005 whether all tribals, leave alone other communities practice polygamy? Every rule has an exception depending on the factors such as financial, political position etc. It is unfortunate that a constitutional body's report has degenerated into such an abysmally ludicrous level.

\subsection{Yakshagana - essentially a tribal art form [2][28]}

Involvement in the folk art of Yakshagana by a few has been unduly emphasized to infer that the Maleru (sic Maaleru) are an upper caste. It needs to be noted that out of the population of a little more than 10000 of this community, probably one or two are involved in this art form. With due apologies, it must be noted that even these individuals have not made a great name in this field. Just as the traditional occupation of temple servant being an occupation in the passing, the Yakshagana too is a few times in a year hobby to them. People from all castes get involved in this art. The Encyclopaedia Britannica describes that Yaksha, in the mythology of India is a class of generally benevolent nature spirits and they are also regarded as a tribe. Hence, it is appropriate to term Yakshagana as a tribal art form. Thus it becomes clear that the authorities are spending enormous resources of the Government to create a controversy where none exists.

\subsection{The diacritic issues and the flimsy basis for the controversy}

Thurston [18] has described the temple servant community as Malēru with diacritic 'e'. This description has been cited in the ethnographic note. Elsewhere, he has written it as Maleru without any diacritic referring to the same temple servant community. He has not described another community of the same name, with or without diacritic. However, N\&I [14] have attempted to make a distinction by writing the temple servant community as Māleru and the primitive tribe as Maleru, both communities supposedly living in the same region. In the book 'Mysore Tribes and Castes' (volume IV, page 185-186)[29], Iyer also writes the name of the temple servant group as Māleru and Mālēru. But, Iyer in Vol.I, Chapter VI, page 219[30] writes it as Maleru (without any diacritic) under the footnote that refers to Vol.IV, p.185 with diacritic of his own work. Sadly, Iyer has not realized that he is paving way for a self-contradiction. N\&I [14] and Iyer's [29][30] writings are replete with such contradictions.

The equivalent definition in Kannada for this practice is called as 'deergha'. This has been the practice of early writers in English to distinguish the long vowel of the native language from which the respective caste name originated. However, a 'religiously' strict adherence to this method was never seems to have been adopted by many writers. Often times it is difficult to make a clear distinction on the basis of the use of diacritic. But we must note that in the presidential order of 1950[1], no diacritic has been used for any community leave alone the Maleru community. Further, in the 1950 presidential order [1], the name Maleru is written in Kannada and Hindi as దூలెீరు and मालेरु respectively, which is given against English version. This is further confirmed by the letter from the Ministry of Tribal Affairs dated 21st October 2013[8]. Most importantly, in the presidential order of 1950, the version claimed by the officials i.e., దులిలరు is not written against the English version. Therefore the authorities are falsely claiming phonetic similarity. Under the animist-Iraliga category too [12], it is written as Máleru (diacritic on 'a') which is obviously Maleru (sic Maaleru). In all these entries, the Kannada spelling is దోలిలరు. It is significant that Maleru written in any form is not mentioned under the category 
'Hunters and Fowlers [12]'. Thus, the categorization of the so called Maleru as hunters thereby implying only such a group is a tribe is without any support from the Census records. Hence, the effort of the authorities to ascribe the tribal character of this community as hunters is utterly prejudicial. However, in no census the English and Kannada versions, Maaleru and దుల่eరు have been mentioned. Obviously, the English version Maleru has been arrived at by considering the spelling and pronunciation of the caste name దోఠతeరు in vernacular. Hence, there cannot be any sensible argument that దులిలరు has been translated as Maleru. Therefore, the two community theory is completely without basis. Also, this has never been proved by any Government survey. Of course the root of the problem is whether a so called genitive tribe Maleru really exists who are different from the so called Maaleru. In reality no such community exists. The Karnataka Government has miserably failed to establish their supposed existence in spite of the might of the state government behind them. The failure is appalling because the manufactured controversy has been in existence for more than five decades. In order to cover up their failure and to try and establish the falsehood, they floated the concept that Malaikudi is Maleru. This is without any basis. If Malaikudi is synonymous with Maleru, then in the presidential order [1], the two names would have been mentioned as synonyms as is done in the case of other communities such as the Kudiya, Melakudi as entry No.27 whereas Malaikudi is at entry No.31 and Maleru is at entry No.34 in Karnataka ST list [1]

\subsection{The spurious distinction of 'villages \& towns' and 'forests \& hills' in Malnad}

In Kannada language Malnad means hilly region. Hence, it is wrong to compare the habitats of plains with that of Malnad. The distinction as people living in 'forests \& hills' and 'villages \& towns' is spurious in regard to Malnad. Large populations of all communities live in places scattered as "single house villages" amidst thick jungle. Each such house has a village name. Barring the few towns and 'townlets', virtually the entire Malnad is forest. But even these towns and villages exist in continuity with the forests. In other words people's habitats, whether villages or towns are situated within deep jungle. That is the essence of Malnad. Hence, the hinted geographical inaccessibility and remoteness of the 'forest and hills' is a construction of the vested interests. The Govt and NCST have indulged in this game as it can cater to the stereotypical city dwelling higher authorities who may have never sufficiently acquainted themselves with the terrain and topography of Malnad. This classification looks ridiculously amusing to a person hailing from Malnad and the intent will not escape from a person of even an average intelligence. Therefore, as described earlier in this article, the very distinction made out as 'villages and towns' versus 'forests and hills' is dubious.

\subsection{The irrational effort to distinguish the tribe on the basis of language -ignorance of Tulu language and the dangerous interpretation}

We cannot lose sight of the fact that since time immemorial there has been marital relationship among different communities between South Canara and Malnad. This applies to Maleru people too. The language is not a barrier. In the Malnad and South Canara region, people have been using Kannada and Tulu simultaneously. In fact, the people of South Canara and Malnad do not make a huge distinction between the two languages as is the case between the people of adjoining regions of two language regions even if they happen to be two separate states. Therefore, distinction such as Tulu speaking Maleru tribe is a construction of the vested interests in the bureaucracy. Since, a large number of Tulu speakers have been living in the Malnad belt, the Malnad Maleru people speak Tulu also along with Kannada. The Mother tongue could be either Tulu or Kannada depending on whether they hail from forest region of coastal districts or Malnad. The emphasis on Tulu language of the so called primitive Maleru has an air of excess in it. This may be an attempt to paint the tribals of Karnataka as people speaking any language other than Kannada. This is far from truth. Gonds, Gowdalu and many other tribes speak Kannada at home. Tulu is the mother tongue of Tulu Gowdalu (Patil)[26].

Morab [26] writes that Maleru, Malaye Kandi, Kudia and Barkedaklu are different nomenclatures of Malaikudi. In the Scheduled Tribe book it has been mentioned that Malaikudi have also been listed as Malayekandi and Maleru. This is an instance of the ignorance and uncaring attitude of the writers about the nuances of a given language. In Tulu the word 'eru' [31] variously means an Ox, a bullock, a buffalo especially of male species or a moth or worm. For example, the word 'aryayeru' means a castrated Ox. Here the letter ' $u$ ' at the end of the word aryayeru is not a diacritic. But there are words where the diacritic ' $u$ ' is used to represent

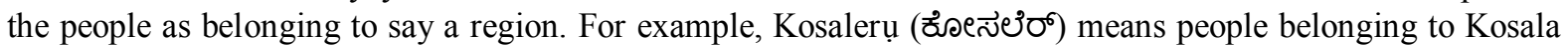
country. Similarly, Malerụ (దులెరా) could be a nomenclature of Malaikudi where diacritic 'ụ' is used. That is, in both the words, the letter 'ụ' at the end is a diacritic. Therefore, the word Malerụ can be దులిరో in Tulu written in Kannada script. In this instance, it can mean as people from hills and not when the word Maleru is written without diacritic ' $u$ '. Further, if they were to be a Tulu speaking community, the way they pronounce the name of their community, the enumerators would have written it as దులోరో and 'Maler' in Kannada and English, respectively, but not as దులోలరు. However these versions in vernacular and English are not found in the Census 
or in the ST list. The obvious conclusion is that such a community does not exist and hence the same cannot be found in the Census. Therefore, it is clear that the latter day writers have not really taken the pain to understand the fine nuance of Tulu language. At this juncture, we must remember that in 1901 Census [1] where excellent care has been invested to write caste and tribe names with the diacritic wherever needed, the word Maleru with diacritic 'ụ' has not been used. Instead, they have written it as Máléru with diacritic 'a' and 'e' but without diacritic ' $u$ '. Hence, it cannot be argued that Maleru in the ST list of Karnataka is a nomenclature or title of Malaikudi. Besides, it is entirely inconceivable that the authorities before 1950 would have allowed independent declarations in the ST list for different nomenclatures of the same tribe. If different nomenclatures were to be provided as independent declarations, then they would have also provided Barkedaklu and Godaru as independent declarations. Of course, these have not even been shown as associated declarations in the ST list. It is clear from the Supreme Court judgment that different names of a given tribe would be mentioned in brackets as a single declaration in the SC/ST list [34]. In other words, the Maleru in the ST list of Karnataka is none other than Maleru (sic Maaleru).

\subsection{Contradictory accounts of the so called primitive tribe Maleru by different writers - misrepresenting some other community as Maleru:}

N\&I [14] have presented a version of the so called primitive tribe Maleru which is an exact word to word and sentence to sentence repetition of the version presented by Thurston [18] describing Hasala which is another community. The entire write up by Thurston is under the title Hasala. The obsequial custom is completely about the Hasalas. However, an intriguing aspect is the one sentence which is missing in the N\&I's version. The sentence in the Thurston's version of Hasala reads as "this may be looked upon as the elementary germ of the posthumous care-taking which finds articulation under the name of sradh in multifarious forms accompanied more or less with much display in the more civilized sections of the Hindu community". This is concerning the custom written by Thurston as: When anyone among them dies, somebody's devil is credited with the mishap, and the astrologer is consulted to ascertain its identity. The latter throws cowries or rice for divination and mentions the name of some neighbour as the owner of the devil thief. Thereon the spirit of the dead is redeemed by the heir or relative by means of a pig, fowl or other reward. The spirit in a pot is supplied periodically with water and nourishment.

It is not difficult to understand that N\&I [14] wanted to avoid mentioning Thurston's [18] suggestion that the practices of the upper castes are an improvised version of the tribal beliefs and customs. Hence the omission is obvious.

It is sad to note that N\&I [14] have presented the version of Hasalas by Thurston [18] as their own. The bigger culpability is to present it as a description of Maleru. This is absolute misrepresentation unbecoming of the persons of such a stature. This is a fake document.

N\&I [14] have also carried out a minor looking alteration in another sentence, but this has major consequence. Thurston [18] writes that "their marriage customs are characterized by the utmost simplicity, and the part played therein by the astrologer is not very edifying'". N\&I [14] have written it as " ...is very edifying", where the word "not" has been removed. In their eagerness to 'repair' Thurston's [18] version, N\&I [14] have introduced absolute contradiction in that sentence. The intent appears to be obvious. The denigration of the astrologer was probably not to their liking. The importance of such alterations cannot be dismissed as minor. In the judgement against Shoba Lakshmi [10], it has been pointed out that "in her school transfer certificate in column No.9 as to whether she belongs to scheduled caste or scheduled tribe it is mentioned as 'not'." In an environment where the revenue officials simply shout away the applicants for a caste certificate, the students could not produce the same. The consequence is that the school authorities will make such a negative entry.

Thurston writes that 'they lead a life little elevated above that of primordial barbarism.' N\&I changes the same a 'little' and writes as "they lead a life above that of primordial barbarism." The question is how much above that of primordial barbarism. If N\&I's version is to be believed, then from 1931 to 2005 did they become more backward to become eligible for the classification as a primitive tribe group?

After a lapse of over 80 years of writing this piece, we cannot sit in judgement on whether this act of plagiarism is the handiwork of some sub staff or the culpability is straight at the door of N\&I [14]. One cannot fail to notice, although with much pain, that wherever the reference is directly to the Hasalaru, that portion has been either omitted or the word Hasalaru is just removed. Thus we can see that the entire portion in page 326 by Thurston [18] is absent.

The consequence is frightening. The NCST has written the obituary of the persons who have obtained Government jobs on the basis of caste certificate and the future prospects of the aspiring youth of this community. The Maleru (sic Maaleru) community is certain that the benefit is meant for them only. Most certainly, N\&I [14] could not have imagined such a turn of event. Leaving aside the ultimate result, the mental agony with which the affected families are putting up in the interim period is nothing short of human rights violation. The authorities should realize the gravity of the situation and prevent a catastrophe in the making. 
We may also note that Iyer has given a detailed account of Hasālar community [32]. However, a similar treatment of the so called primitive Maleru tribe is conspicuous by its absence except for the brief sketch which is actually a description of Hasalaru by Thurston [18]. The Malēru whom Thurston had referred as 'Hasalaru and Malēru', are probably a few abandoned persons upon excommunication. This is obvious from the fact that Thurston has used the same regime of diacritic for the word Malēru in 'Hasalaru and Malēru' as for the temple servant Malēru. The distinction of hills and towns being a spurious distinction in the case of Malnad, the extraordinarily keen observer Thurston has naturally judged that the Malēru in 'Malēru and Hasalaru' are none other than the temple servant group. Therefore, it is not surprising that Thurston has not provided the description of a separate primitive tribe Maleru. Obviously, there was none to do so. This assumes importance because Thurston [18] has cited N\&I [14] on many occasions. The NCST has based their conclusion upon this single piece of literature as the primary evidence to claim the existence of a primitive tribe Maleru different from the Maleru (sic Maaleru). The consequence is that the real Maleru (sic Maaleru) have been put to unmitigated agony in the last 50 years. Therefore, this account of Maleru by N\&I [14] should be out rightly rejected since it describes Hasalaru and not Maleru. Obviously, N\&I [14] have indulged in an act of plagiarism. The motive for the same could be as follows. They could not tolerate the denigration of the astrologers who are most often Brahmins. Therefore, the intent to repair Thurston's version is too obvious to be ignored. However, N\&I [14] have given a separate, detailed description of Hasalaru as mentioned at the beginning of this paragraph. Therefore, when faced with the dilemma of the fate of repaired version, they found it convenient to paste it under the title Maleru. The sad part is that they have contradicted themselves. A community supposedly living a life of barbarism and in a remote forest most probably isolated from the mainstream society would not engage the services of an astrologer or a priest. Also an astrologer or a priest would not find it sufficiently remunerative to trek to a remote forest to attend to an impoverished client. Hence, the edifying role of an astrologer simply does not fit into such a living.

Thurston [18], N\&I [14] and others of their ilk are legends in the fields of ethnography and social science. Their services to the Indian civilization are immense in terms of recording ordinary people's attributes. However, no work by an individual can escape the imprint of his attitude towards various aspects of human existence. Hence, it is very natural that certain aberrations cannot escape the works of such monumental nature. Hence, the plagiarism cited is probably an isolated case and citing of the same should not be construed as unwarranted criticism but should be seen as an open minded approach to appreciate as well as understand the deficiencies in any work. Thurston's description of Maleru (sic Maaleru) women as prostitutes and of bad character probably falls in this ambit. This also applies to Thurston inserting the name Maleru in the description of Hasala. Therefore, the authors of this article are contemplating a comparative study of the works of Thurston [18] and N\&I [14]. Of course, this description of Maleru (sic Maaleru) is in striking contrast to the NCST's view that they are a high society people. It is pertinent to note that even now there are no MLAs or MPs leave alone ministers or industrialists or big estate owners from this community.

\subsection{Divergent views - the hollowness of theory of a primitive tribe Maleru.}

We divide the description of the so called primitive tribe Maleru in the literature into essentially three groups. In the first group we have the writings by N\&I [14], in the second group that of Luiz [15] and in the third group by a few other authors. The three groups encompass a period of over six decades. We term the last group as later day authors [16] since their writings correspond to a period later than the 1980s. A clinical examination of these versions yields an extremely contradicting picture.

Luiz [15] says that the so called primitive Maleru treat Chamars, Madigas and Hasalarus as low and avoid them whereas N\&I's[14] version of Maleru is Hasalaru itself and hence no mention is made about the attitude towards later. Besides, a tribe which treats other similarly disadvantaged castes as low cannot be said to have suffered any isolation which is an essential requirement for being considered as a tribe. He writes that they are short, dark skinned and curly-haired, and some have the external features of the Dravidian primitives. The question that naturally arises is 'why only some have Dravidian primitive features'. This inference assumes importance because of the wrong notion that the tribes need to remain in splendid geographical isolation from the rest of the population to claim the tribal membership. Only such a geographical isolation would have ensured Malerus having Dravidian primitive features. Are they the (sic) Maaleru after all? According to Thurston [18], even the Malekudiya have mixed features due to contact metamorphosis. Luiz [15] also describes that probably the origin of Maleru is North Canara district of Karnataka. This is does not stand the test of proper scrutiny because Tulu is not spoken in North Canara whereas Kannada is the language of that region too. He writes that they appear like the Pallavs. But Pallavs were great kings who ruled over Tamil country. So the Maleru described by Luiz [15] have a royal lineage? In that case, their language should have been Tamil and not Tulu. Anyway, how did Pallavas look like? Iyer writes that Hasalars are Pallavs. This leads to the view that the primitive Maleru were a variant of Pallavs. History says that Pallavs may have arrived from the North India and they have used Sanskrit and Prakrit rather than Tamil. Luiz [14] further says that the modern Malerus like to be 
known as Hindus. This was before 1963. So the conclusion is that they were not a rabidly geographically isolated community even by 1963 . However, the NCST expects the (sic) Maaleru to be animists leading an isolated existence on a hill top even in the year 2005 to be called a tribe. His version of Maleru does not remember any clans.

The descriptions by later day writers (see sec.9.7) clearly reveal that they are a vibrant community with rich details such as clans, marriage, and birth and death rituals. One wonders, whether multiple clans evolved within two decades from the time of Luiz [14] to the time of latter day writers. So, these primitive Malerus are not as primitive as is made out to be. The later day writers nowhere mention that they are impoverished so as to survive on roots and hill ants. However, the authorities strive to prove it otherwise. He writes that their (primitive Maleru) marriage is solemnized with the groom tying taali (Mangalasutra) in the presence of elders. However, the same practice by (sic) Maaleru is found to be objectionable for considering them as a tribe. Liuz[14] also says that a Maleru girl attaining puberty is segregated in a shed put up for the occasion and later burnt. The girl has to bathe and go through a series of purification ceremonies before she can be admitted into the family hut. After childbirth the mother is treated as polluted for fifteen days and, thereafter, as unclean for three months. Therefore, this version of Luiz [14] must lead one to conclude that they are not so primitive but a community on par with the upper caste.

Patel [16] and other later day writers mention that Maleru are found in Dakshin Kannada, Shimoga and Chikmagalur districts. They are presented in rich details about various aspects of their life including good utilization of ration. On the contrary, the letter of D.C. of Shimoga dated.01 March, 2005 [19] states that Maleru have probably become extinct. In that case did they become extinct in a decade in Shimoga District? The NCST reports that they barely survive on a hill top in Chikmagalur District who are said to be on the verge of extinction as they are supposedly surviving on tubers and hill ants and hence deserves to be put in primitive tribe groups (PTG). In their eagerness to eliminate Maleru (sic) Maaleru from the ST benefits, the authorities appear to be re-writing the requirements of a group to be declared as a PTG. The contradictions seem to have no end.

One common strand that runs through the writings by later day authors about both the Malaikudi and Maleru communities is about the belief that they were given the right to collect wild cardamom by the legendary Pandavas when the later were supposedly under exile in this area. Gurikara (headman) is another common trait mentioned about both the communities. The clan names, the rituals at birth, puberty, marriage and death are strikingly similar to both the communities. There appears to be numerous spelling and factual errors. Luiz writes that Maleru or 'Malarau' are at times known as 'Male Maleru'. The spelling 'Malarau' is not seen anywhere else which is obviously a spelling mistake. Patel writes Maleru as 'Maleur' and 'Maleuru' where the last two words are spelling mistakes. Further, he mixes up the writing of N\&I about the excommunicated persons. Morab[16] writes that Malaye Kandi, Kudia, Maleru and Barkedaklu are different nomenclatures of Malaikudi. But he also writes that Godaru and Barkedaklu are titles. If titles and nomenclatures are the same, then there should be four titles or two nomenclatures. Further, if Maleru is a nomenclature, then it is irrational to provide a separate description under the head Maleru as though it is a tribe distinct from Malaikudi. Morab [16] mentions that the population of Malaikudi was 211 as per the 1971 Census. In the same volume, Patil [16] writes that the population of Maleru is 321 as per the same 1971 Census. The contradiction is apparent that population of Malaikudi with four nomenclatures is less than the population of a single nomenclature Maleru.

While Morab [16] writes that Kudi in the word Malaikudi means family, others give the meaning as hill top. Two problems appear to have played havoc. While, on the one hand the census enumerators may not have accurately recorded many details, on the other, the writers, many of whom may not be Kannada/Tulu speakers too have grasped and presented details with lots of errors. Therefore, it must be noted here that the abundant wisdom of the Supreme Court is amply reflected when they have termed Thurston as an authority on the caste and tribe descriptions in more than one judgment. Thurston has adhered to the highest degree of professionalism.

Further addition to the contradiction comes from Rice [2] when he has referred to Maleru as Maleyas, somewhat resembling Soliga and found along the ghats on the western frontier of Southern Mysore. So Maleyas were called as Maleru? Among the Bedas there is a community by name Mallar [14]. Hence we suspect that they may have been misrepresented as Maleru probably due to clerical error. The later day authors and Luiz have displayed a devil may care attitude to the spelling of the name Maleru. They have written it as Maleur, Maleuru and Malarau. Even the word Tulu has been written as Tule. It amounts to calling all people in Malnad or forest region as Maleru. Hence, a natural inference that can be drawn from these diverse versions is the following.

The description of the so called primitive Maleru by N\&I [14], Luiz [15] and the later day writers [16] forms a 'dubious troika'. Each version is divergent from the other two. Every rule has an exception. The scholarly writers may have unfortunately erred on the wrong side. They may have mis-represented other tribal groups such as Malekudiya as Maleru albeit unintentionally. Possibly taking a cue from this, the NCST have deliberately concluded that Malaikudi is Maleru. This conclusion has been arrived with all the seriousness at 
command. The consequences are grave. The authorities have come to the conclusion that the primitive tribe Maleru have all but ceased to exist except in one place called Alekhan Horatti. If the establishment continues to hold to the view that a different primitive tribe ever existed before, then they have to become liable for the extinction of a tribe which amounts to criminal negligence on the part of the Government. Therefore, they could not conclude that the primitive Maleru has become extinct. Therefore a twist in the tale suits the purpose which came in the form of a conclusion that Malaikudi are Maleru. Hence, it becomes convenient for NCST to conclude that the population figure of Malekudiya include Maleru in Mudigere. A grand merger indeed that speaks volumes on the bureaucratic apathy and duplicity.

Hence, a natural conclusion is that the literature is worthy of being discarded without even a second look. Consequently, the NCST's argument and the decision thereof are not correct. The fact is that there is only one Maleru who are described as 'temple servants' and they are the true inclusion in the STs.

An important fact that emerges from a reading of the literature by these authors is that most of the tribes are not suffering from any geographical isolation or socio-economic backwardness. In this context it is important to note that communities like Gonds accept water and cooked food from the Brahman and Maratha communities only [16]. If viewed seriously as per the NCST view, many communities no longer justify their continuation as STs.

The NCST has declared that in Alekhan Horatti, the so called primitive Maleru are now claiming to be Malekudiya. This leads to the following conclusion. Either, the authors who have documented the tribe Maleru are wrong because they have not concluded that Maleru are Malekudiya or the NCST is wrong because it has concluded that Malekudiya are Maleru. In reality, while the NCST has concocted a fiction, the earlier authors have in all probability misconstrued some other community as Maleru. The later day authors have dished out the details of Malaikudi as Maleru as though they are writing a fairy tale. This is the consequence of an arm chair job. Only a forthright Govt can be expected to appoint a 'truth commission' probably consisting of foreigners, to obtain an honest understanding of the contradictions and establish the hollowness of the two community theory.

It will not be out of place to narrate the following. As per N\&I [14], if a Kuruba woman was cohabiting with a man of different caste, generally lower, the punishment prescribed was compelling her to live in Mādiga quarters. There is no wonder the authorities in future may declare Mādigas as Kurubas and deny them the SC benefit. They have probably found a sure way of dismantling the social justice framework.

\subsection{Failure to enumerate the two communities - a natural consequence of the falseness of the two community theory}

Since the 1960s the authorities have been claiming that two communities exist. Hence, the Govt should have taken steps to mention the population counts of both the communities separately. Also the NCST should have done the same when they 'took a series of action' to gather some basic information about these communities. It is not a minor error but the one that has the dangerous potential to deny the constitutionally given benefit to an entire community and also provides an opportunity to the authorities to hoist criminal cases on the members of the Maleru (sic Maaleru) community.

\subsection{The traditional occupation of Maleru (sic Maaleru) - a thing of past.}

The descendants of the few who were temple servants have ceased to remain the same, long before. The very concept of Maleru (sic Maaleru) people being the 'traditional temple servants' no longer exists and has become a relic of a distant past. Hence, the emphasis[2] on the traditional occupation of Maalerus as 'temple servants' even in the year 2005 smacks of the ulterior motive of hoisting a non-existent occupation on this community with the ulterior motive to paint them as a forward community.

\subsection{The falseness of abject poverty of so called primitive Maleru.}

The NCST has mentioned that the so called primitive Maleru have nothing to eat in the lean season [2]. It is strange that except this supposed finding no Govt report has mentioned anything even remotely similar about any community in Malnad, whether in villages \& towns or in forests \& hills. Even the later day writers [16] do not agree that their version of Maleru have nothing to eat in the lean season. It's a region rich in natural resources such as water. Of late, a number of migrants from Kerala have been growing commercial crops in the 'forests and hills' of Malnad, virtually minting money. It makes an amusing story to read that the so called primitive Maleru have nothing to eat in the lean season. If Govt sincerely believes that the Maleru tribe really existed and has now become almost extinct except in one packet, then it is a fit case for charging the Govt with negligence for letting a tribe become extinct.

\subsection{Thurston's authority questioned.}

Much of the NCST report is based on the input by the state authorities. The letter by Negi [36] is a classic example of prejudiced judgement. He mixes up the version given in the People of India, Volume - III 
[26] in which the description of Malaikudi misrepresented as Maleru is given with the description of temple servants given by Thurston. If this version is to be accepted, Mr.Negi should provide the identity of the descendants of temple servants. Are they not Maleru (sic Maaleru)? The temple servants are none other than the present day Maleru (sic Maaleru). This is also the essence of ethnographic note. Again in the letter dated.10th February 2005[36], the same officer says that Malēru has been correctly written as Maleru. However, Negi interprets that it has been wrongly translated into Kannada as మోఠృోరు. It is unfortunate that the officer conveniently forgets that the Thurston explicitly describes Maleru as temple servants which is none other than Maleru (sic Maaleru or aోత3eరు) as per the 1901 Census of Mysore [12]. Therefore, he has to clarify whether the ST status is available to temple servant Maleru because his letter defends the description of temple servant Maleru within the overall description of Maleru. It is a sad commentary that the high officer has cared little to distinguish such contradictions. It is obvious that neither he nor his representative officers such as Deputy Commissioners of the districts concerned have personally visited and met such people.

The supreme Court have considered Thurston as an authority but the state Govt and NCST brushes aside his account and gives weightage to other writers views which are mutually contradictory. The descriptions of N\&I and those of others are a clear testimony of the same. In 1881 and 1891 Censuses, the Maleru was written without any diacritic while in 1901 census Maleru has been written with diacritic. In the Census for the three periods mentioned above, the traditional occupation is indicated throughout as temple servants. This establishes that it is the so called phonetic similarity Maaleru which is correctly written as Maleru that has been included in the ST list. Besides, when Thurston has described about so many castes/tribes from all sorts of inaccessible areas, the suggestion that he may have probably missed documenting the so called primitive Maleru is to attribute lack of professionalism to the authority of Thurston.

In the NCST report [2](page 216, item (f)) it has been mentioned that "Information easily available in the urban or rural areas about MĀLERU COMMUNITY might have been mistaken for the MALERU tribal community. Records also reveal that British Govt, in India has devised separate policy for inaccessible and tribal areas and details of each tribal community would not have been actually available to the then government machinery. Thus the description of MĀLERU community (rather families) has been described for MALERU community. It is also worth noting that description contained in this book does not touch upon any resemblances to tribal features."

When the early Census enumerators have listed a humongous number of primitive tribes from remote jungles, to suggest the omission of the so called primitive tribe Maleru because 'the British had different policy to such areas'[2] is to attribute motives and question their professionalism. If "the details of each tribal community would not have been actually available to the then government machinery [2]", in the first place how did the Govt included such a tribe in the ST list about which no details was available? Did the Govt include an imaginary primitive Maleru in the ST list? It also amounts to authorities admitting that the 1901 Census entry of Forest and Hill tribes Maleru is the (sic) Maaleru and not the so called primitive Maleru. On the other hand, the existence of Maleru (sic Maaleru) in Malnad region has been known to everybody, since time immemorial. Therefore, the very supposition that a different primitive Maleru was only included in the ST list must necessarily have been followed by the insertion of an exclusion class for the Maleru (sic Maaleru). Hence, the claim of NCST is self-defeating. Further, the reference to the 'tribal features' in the year 2005 is to expect all the tribals to be wandering in remote jungles with virtually no dress etc. If it is a reference to their physical features, then the comment is amounting to racism. It is necessary to remember that some tribes such as the Toda look like Europeans.

\subsection{The inter caste marriage and the caste of children from such marriages.}

The general rule adopted to determine the caste of the offspring of intercaste marriages is that such children will inherit the caste of the father. However, the Indian society doesn't operate like that. Therefore, the following questions gains great importance. Whether the marriage of a non-brahmin to a Brahmin results in accepting the non-brahmin spouse as Brahmin? Further, whether the offspring of such marriages will be recognized as Brahmins? The Brahmins will never accept such beings as one among them. That is the antitheses of Brahmanism. In this regard we must note a general principal of nature. That is, a person - any living being for that matter - loves himself/herself much more than loving any other person-be it his/her children, spouse or parents. In the same manner, in India the caste pride is equivalent to love of oneself. Thus, the net result of inter caste marriage is that on the one hand the caste of the higher caste spouse will in practice get degenerated and the offspring in general are not accepted by either caste.

The caste pride and the decision at community level are so strong that even the lowest castes do not in general admit such persons to their caste. Thus, the ultimate result is that such couple and their offspring are relegated to the ignominy of casteless existence. Such an existence is worse than even belonging to the lowest caste. This state of existence has been poignantly described by the French traveller Abbe Dubois [23]. It is important to note that the Supreme Court has laid down that the caste of the offspring of intercaste marriage will 
be determined on the basis of the upbringing of children. But Indians being caste conscious to a fault, the upbringing of the children can never be practically according to the caste of the higher caste spouse. Even, the lower caste spouse will not be able to satisfactorily impart all the caste customs according to his/her caste because most caste customs get ingrained only with the regular interaction with other members of the caste. The result is a poor admixture of customs which will not be acceptable to either caste. The net result is a thoroughly degraded caste/tribe. In other words they become an untouchable caste/tribe. The reader has to keep in mind a social situation of the 19th century to appreciate this scenario.

\subsection{Procedure followed in the Dhangar versus Dhangad issue [27]}

In the Dhangar versus Dhangad dispute, the NCSC has at least mentioned that they have interviewed 132 persons and verified the ration card and other revenue records in two districts of Mathura and Agra of UP to conclude that only Dhangar community exists and no Dhangad community exists and hence SC certificate need to be issued only in the name of Dhangar caste. In this instance, the NCSC do not appear to have proceeded with any prejudice by virtue of the fact that there appears to be no effort to create an imaginary community. However, in the case of Maleru issue, the NCST have confined their venture to a brief visit to a hill top. Rest of their effort is to prove that the so called Maaleru are not tribals. Otherwise, their effort is all about meeting state officials.

The NCST says that the so called temple servant Maleru (sic Maaleru) is not ST. From the 1891 onwards, Maleru (sic Maaleru) entry can be found in all the Census records. From about 1970s the Govt have been saying that there are two Malerus. One the so called primitive Maleru who are supposed to be the real ST whose population in 1981 was 966 and the other Maleru (sic Maaleru) who are temple servants and not supposedly the STs. In other words, they have discovered that there are two communities the names of which were written in the same manner in English. This amounts to a discovery of a new community. Alternatively, they have been either enumerating the so called primitive Maleru or the so called temple serving Maleru (sic Maaleru) or clubbing both all these years. Therefore, the Govt needs to answer as to which community they 'discovered' by 1970s. This is a purely academic question because in the absence of a so called primitive Maleru, the only community enumerated was (sic) Maaleru. Ofcourse, they have found an escape route by claiming that Maaleru have been probably enumerated as Brahmins which is utter falsehood [2]. An honest verification of Census records will prove the existence of Maleru (sic Maaleru). Also after this controversy, whether they have taken steps to enumerate these two communities distinctly?

\subsection{Issues such as religion, genes, dress}

The constitutional order specifies that an ST can belong to any religion. The Toda \& Kota have shared genes which separate them from the other Nilgiri Hill Tribes and share their closest affirmity to the Greek Cypriots [26]. The Toda dress consists of a single piece of cloth, which is worn like the plaid of a Scottish highlander over a dhoti for men and skirt for women [26].

\subsection{Tribes need not be compulsory hunter gatherers}

The authorities seem to presume that all ST communities are hunter gatherers and must continue to remain so to prove their credentials of being included in the ST. A contrary example is, the Medas which is an ST community who are mat makers and Cane splitters [26]. Also it must be noted that in the 1901 Census [12], the Maleru community has not been included in the category of hunter-gatherers. Hence, the emphasis on Maleru as hunters is without basis.

\subsection{Futile search for the name Maaleru}

The letter by Anthropological Survey of India (ASI) [2] states that no reference is available to suggest that Maleru is also known as or spelt as Maaleru. That amounts to an indirect admission that only one community exists whose name is Maleru and the name Maaleru is an invention of the officials. Unfortunately, the ASI had relied upon the description given in people of India [26]. It is sad that they too have not given any credence to the ethnographic note which is a Govt document.

The note by the Office of the Registrar General of India (RGI) [2] states that they are not in a position to throw any light on the question of explaining the circumstances under which Maleru was specified as a Scheduled Tribe. They too pass the buck to the Home Ministry. This speaks volumes about the lack of professionalism on the part of the authorities. While the RGI has not lived up to its responsibility, it has added its own weight to the controversy by defending the N\&I's version. It is a horrendous blunder that they too have not discovered the plagiarism of N\&I. Any responsive Govt would have obtained a clear and unambiguous picture of each and every community before including the same in the reserved category. If the same is absent, it amounts to dereliction of duty on the part of the Government. A hapless community should not be made a scapegoat for such culpability. 


\subsection{Probable victims of the lack of clarity on STs}

In the NCST report [2], it is written that "there are some examples where a community which may not possess any tribal characteristic, yet may find a place amongst the STs".

Whether Maleru (sic Maaleru) were included in the like manner? The report is silent on that score. It would have been appropriate to cite examples of such communities. Even if this contention is true the members of those communities are not at fault. The humane method is to establish that fact, decide on the appropriateness of their continuation in the existing category and if not fit, arrive at a decision to treat them under any alternative dispensation. Essential requirement is the guaranteeing of the job security of such employees. The Govt. Order dated $11^{\text {th }}$ March, 2002[35] which guaranteed the jobs is a step in the right direction instead of hoisting the criminal cases, threatening arrest and allowing the controversy to linger on.

\subsection{No counter claim by another community}

An important component of the issue is that in the history of over 50 years since this controversy has been raised by the authorities, no individual or organization has complained that the benefit meant to their community has been appropriated by (sic) Maaleru. Obviously this would have been the case if there were to be any reality in the controversy. This is an important evidence to conclude that it is a manufactured controversy. Further, if the NCST is very sure that Maleru tribe has now become extinct then they should recommend its deletion from the ST list rather than recommending its inclusion in the Primitive tribes. Most importantly, Supreme Court has pointed out that, "Wherever one caste has another name it will be mentioned in brackets after it in the Presidential Order, therefore, generally speaking, it would not be open to any person to lead evidence to establish that caste B is a part of caste A notified in the order. No court can come to a finding that any caste or any tribe is a Scheduled Caste or Scheduled Tribe. Scheduled Caste is a caste as notified under Art.366 (25). A notification is issued by the president under Art.341 as a result of an elaborate enquiry. The object of Art.341 is to provide protection to the members of SCs having regard to the economic and educational backwardness from which they suffer...disability of untouchability alone is the basis to declare a caste as scheduled caste cannot be appreciated" [34].

Hence, natural justice demands that this principle must apply not only to individuals and communities but also to the Govt especially when a section of them are committed to show a community in poor light. In the case of Maleru (sic Maaleru) community, the members have written their community name as Maleru in English and దోలెeరు in Kannada since over 100 years. This is exactly the style found in the Presidential Order of 1950[1] and the Censuses over the years. Hence, to name this community as Maaleru and pass the judgment that they are false claimants (especially when no counter claim exists) is an act against the Presidential Order, 1950 [1] and against the decision of the Supreme Court [34].

\subsection{The benevolence of the NCST [2]}

The Maleru (sic Maaleru) community has reason to be deeply indebted to NCST for the following kind remarks about that community. Their report says that "Maaleru (मालेरु) community is an exploited section of the society. Justice has to be given to the Maaleru community and such other communities/families suffering similarly in other parts of the country". After the display of benevolence, it would have been justice if they were to recommend the nature of justice deserved by this community.

\subsection{The culpability of the authorities}

The NCST report says that "when officials denied issuance of certificates to the real Maleru, they were forced to take certificates under Malekudiya tribal name. This has been proved during the enquiry" [2].

This admission of NCST amounts to the committing of criminal offence by the individuals who obtained the certificates and by the authorities for issuing the same because when authorities are claiming that they are Malerus, application and issuance of such certificates in the name of Malekudiya which is an another community is a crime. Besides, in the ST list Malekudiya is not mentioned. That is an added offence because Malekudiya is not the entry but only Malaikudi is the entry in the ST list. The Supreme Court has recognized the sanctity of the spelling of caste and tribe names in reserved category lists.

\subsection{The challenge and the daunting task}

The challenge before communities such as Maleru (sic Maaleru) is to prove that their claim is genuine. They didn't ask the Govt to include their name in the Schedule. Those who included it are not in power anymore. Their successors are proving to be unworthy of being their successors. A class of skeptics exists in our midst who declares that Neil Armstrong never landed on the Moon and what is being shown is an animated film. How can one prove that a community such as a primitive Maleru other than the existing community never 
existed? Anyone who has a reasonable knowledge about Malnad knows for sure that there is only one community of this name. No document of the Govt proves the existence of another primitive Maleru in the past. The description by various authors is plain misrepresentation and also mutually contradictory. The Govt claims that they are extinct in one district while in another they misrepresent another community as primitive Maleru. The people's representatives, the Dalit association (see sec.X) and even the religious institutions have categorically committed in writing that the official version is false. The NCST is not even bothered to do a cursory survey of the region except a flying visit to a hill top. They must have been sure that any amount of effort will not result in discovering the desired group. And yet they deny the truth. How can one prove the existence of something which was never there? That is the daunting task.

\subsection{Advantage Maleru (sic Maaleru) community}

A thorough examination of the issue brings to fore the advantage accrued to the Maleru (sic Maaleru) community. The so called 'authoritative texts' have been proved to be unworthy of any reliability. The authorities and the NCST have affirmed that so called primitive Maleru do not exist in Malnad except in one place who are actually Malaikudi and not Maleru. The documents such as the Mysore Census of 1901, the letter enclosing the ethnographic note, the letter from the Ministry of Tribal Affairs etc. have unequivocally affirmed that it is the so called phonetic similarity Maleru (sic Maaleru) who are the true entry in the ST list. Therefore, the entire exercise is to the advantage of the Maleru (sic Maaleru) community. At least now, the authorities should sit up, accept the reality and resolve the issue in a manner that does justice to the Indian Constitution.

\section{Popular Support}

\subsection{Support by the Dalit organization [33]}

Karnataka Dalita Sangarsha Samiti (KDSS), an organization of Karnataka Dalits have in a lengthy letter dated $20^{\text {th }}$ August 2000 made it abundantly clear that the controversy is completely false and there exist only one community by name Maleru (sic Maaleru) who are the real ST community. We give below a brief summary of their letter. "A community by name Maleru (sic Maaleru) are living in the districts of Chikmagaluru and Shimoga who are the true beneficiaries of ST category. In the past they have suffered on account of being subjected to Devadasi system. Lately, a controversy has been generated that there exist two communities namely, Maleru and Maaleru which is false and the members of this community are being subjected to unnecessary harassment. As soon as this issue came to our notice, we visited several places in Mudigere Taluk of Chikmagaluru District where the so called primitive tribe Maleru are living. But we found that they are a different community by name Malekudiya. From our investigation, we found two distinct ST communities namely, Maleru (sic Maaleru) and Malekudiya in this region who eke out a living by labour, collection of forest produce etc. It is clear that no other community by name Maleru which is different from (sic) Maaleru exists and hence it is very clear that it is a manufactured controversy. Hence we urge that Maleru (sic Maaleru) are the true beneficiaries of ST and their facilities in the ST category must be continued."

\subsection{Support by the people's representatives [33]}

While the Maleru (sic Maaleru) community was at a loss to find ways and means to convince the Govt. that the controversy is not genuine, a stream of people's representatives came forward in support of the fact that no two communities exist and it is only Maleru which the authorities started to write as Maaleru by adding an extra letter ' $a$ ' to force the Kannada version. There have been letters by the MLAs (Members of Legistlative Assembly) of Coorg and Dakshina Kannada Districts addressed to the Social Welfare Department of the Govt of Karnataka, clearly and unequivocally indicating that only one community exists in this region and they are the ones to whom the reservation was provided for obvious reasons of social and economic backwardness and specific characteristics of the people that were representative of a tribal group. Similar letters of support have been issued by almost all elected local bodies of this region. However, the bureaucrats typical of their mindset of imperialism and red-tapism, paid no regard to such extremely valuable evidence. Here it must be emphasized that in a democracy, people's will as represented by the opinion of their elected representatives should prevail. This is because, the people's representatives are first of all locals and have thorough knowledge about their people and also they are answerable to their electorate. If they falsely lend support to a community which is an acute minority in this region, they will stand to lose the support of the remaining population which is a few hundred times more in magnitude. Hence, no elected representative will commit in writing to a false premise. Besides, the officials posted to a given region are largely from other regions and stay in a given jurisdiction for only a limited period before they are transferred to a different jurisdiction. This renders them to possess only a limited knowledge about the nature of people residing in the area. This clearly establishes the dubious intent indicative of their prejudiced mindset and a pre conceived approach which resulted in wrongly concluding that two communities exist. And the last but not least, the Hon'ble Supreme Court through a catena of judgements 
has held that entries of the Presidential Order under Article 341 shall have to be taken on their face value and they are final [34].

The Government order dated.11 $1^{\text {th }}$ March, 2002[35] is evidence that at the highest level of the Government, there is sympathy for such communities because they realize that the communities are not at fault. The summary of this order is that the admissions/appointments which have become final shall not be disturbed. This is eminently justifiable because if a Scheduled Caste employee converts to any religion other than Hinduism, Sikhism or Buddhism, he will only lose the promotional advantage of SC quota and not job. The officials have a monumental role to play without which the political leadership cannot function.

\subsection{The purpose of reservation and the current reality}

\section{Govt needs to reflect}

The very purpose of preferential treatment of select communities is to enable them to develop on par with the larger society. Therefore and particularly due to the scientific and technological advancement in the last half a century, no community has been able to retain all its anthropological moorings and kinship characteristics and the change has been drastic. Therefore, we take note of a study titled 'Karnataka Rural Water Supply and Environmental Sanitation Project II'. The report says that there are 0.073 million STs amounting to $3.6 \%$ of the total population in the project area. But all the STs are totally integrated into the social mainstream. It is very difficult to identify them as a distinct group. They do not fulfill any of the five characteristics stipulated in the operational directive (OD). They live together with other caste groups such as Lingayats, Kumbaras, weavers and the like. They do not have their own language or distinctive dress. We may note that "the term 'indigenous' is a misnomer in a multi-cultural and multi-ethnic India context."[37]

\subsection{The need for a reworking of the $\mathrm{SC} / \mathrm{ST}$ quota}

From a host of disputes that have risen ever since the promulgation of the Presidential order of 1950[1], there appears to be a great difficulty for the authorities to accept the claim of several communities as being included in SC and ST. The difficulty appears to be acute in the case of communities in ST because of a variety factors which include lack of deep interest on the part of officials to get to know firsthand about the people they are supposed to take care coupled with the notions such as the aboriginal tribe. Unfortunately, the mindset of the officials is still one of the "governing" which is a relic of imperialism than the independent India's need for caring the governed. Therefore, the application of a blind set of guidelines to describe a Scheduled Tribe community coupled with a heavy dose of prejudice drives one to reject the claims and strive heavily to create imaginary communities where none exist. The stereotypical attributes of a tribal may not necessarily be applicable to all communities included in ST. Therefore, we suggest the creation of a new list namely, Scheduled Communities (SCom) to include such communities from the present SC and ST lists who may not satisfy the rigid, hard and fast attributes anticipated from the SCs and STs and yet similarly dispossessed. This involves trifurcating the SC and ST quota into three parts. This should not be a difficult task as the communities pulled out from SCs and STs will be accommodated in SCom. This should not agitate the communities who remain in SCs and STs as the reduced share of the quota will be shared from the lesser number of claimants among them. Probably, the NCST had implied a similar dispensation [2] when they made a reference at more than one place in their report about the injustice caused to Maleru (sic Maaleru) community.

\subsection{Inability of the officials in understanding the distinction between the SC and STs.}

A close examination of the approach of officials to the issue of STs reveals an extremely disturbing trend. It is abundantly clear that they make no distinction between the SCs and STs. They look for the attributes of the SCs in STs. This indicates a complete absence of the appreciation and understanding behind the wisdom of dividing the communities into two groups viz. SC and ST. The NCST report on the Maleru issue is a glaring demonstration of the same. This calls for immediate action by the Government to clearly lay down the characteristics of both groups and establish clear distinction and enact suitable legislation. Not addressing the same will lead to many more controversies and the undue harassment of the deprived sections.

\subsection{Avoidable insinuation}

It is mentioned in the NCST report that (sic) Maalerus are not hostile and no cases of atrocities are reported by them or against them. It makes one to wonder whether that is a perfect ambience to ill-treat this community in a manner as being portrayed in the report. It is unbecoming of a constitutional body to ridicule such a community as possessing intellectual engineering brain. This community has not robbed the benefit meant for any other group. On the contrary, it is a victimized community in every sense. The bureaucracy simply doesn't get out of their ivory tower.

\subsection{The supremacy of the Parliament}


The Parliament of India is supreme and if in their abundant wisdom, they consider it fit to delete any community from the SC/ST list, then that should be done by following the due process of law. The creation of imaginary communities and false controversies is no solution.

\section{Conclusion}

While the bureaucracy in India is largely honest and efficient, it is only natural that like in any group, here too a small but vehement and shouting group exists that is bent upon denying the constitutionally given benefits to deprived sections of society. They are capable of inventing arguments essentially meant to harass the helpless communities. If the officials believe that some communities have progressed to an extent that they no longer deserve to derive the constitutionally given benefit, then they should present the facts to the Government and get the community deleted from the scheduled list by following the due process of parliament. It is acutely inhuman to harass helpless individuals by dubbing them as false claimants of reservation, foist on them criminal cases, threaten them with arrest and dismissal from the job. Manufacturing false communities is no way to properly solve the problem. Such attempts by the establishment are a relic of the imperial mindset. The revenue officials should do the hard work of acquainting themselves with the real people by visiting the nook and comer of their jurisdiction and desist from coming to false conclusions sitting in their ivory tower. Independent India's administration should be really people friendly and serve the purpose of properly implementing the Government schemes. That is the highway for manufacturing a new India.

We thank the anonymous referees for their kind review.

\section{Acknowledgements}

\section{References}

[1] The Constitution (SCs) Order, 1950 \& the Constitution (STs) Order, 1950

[2] NCST report on Maleru community, 2005

[3] Supreme Court Judgment of Kumari Madhuri Patil, 1994

[4] Manjunatha B.R., and Annapurna M., 2012, Antrocom Online Journal of Anthropology, Vo1.8, No.2, pp.421-427

[5] A.Mitra, 2007, The Journal of Socio-Economics- Article in Press, Elsevier Publication

[6] Gurajart High Court Judgment for Citation about Baxi Commission Report, 1987

[7] B.B.Kumar; http://www.asthabharati.org/Dia_July99/bbk.htm

[8] Letter of Ministry of Home Affairs with Ethnographic note on Maleru community, 1984

[9] Letter by the Ministry of Tribal Affairs, Govt of India dated.21st October 2013

[10] Karnataka High Court Judgment of N.Chandrika, 1985

[11] Karnataka High Court Judgment of Shobha Lakshmi, 2007

[12] Mysore Census of 1901

[13] Karnataka High Court Judgment of Shantala G. Rao, 2004

[14] H.V.Nanjundayya, \& L.K.A.Iyer, The Mysore Tribes and Castes, Vol.IV, 1931

[15] A.A.D.Luiz, 1963, The Tribes of Mysore, Published by G.S.Viswa and Co., Bangalore

[16] Later day writers:

(1) People of India: Karnataka Volume.XXVI - Part TWO. General: Editor:K.S.Singh

(2) The Encyclopaedic Profile of Indian Tribes, Vol.III edited by Sachchidananda andPrasad,R.R. 1996

(3) The Scheduled Tribes book.

[17] Govt of Karnataka order of 1968

[18] E. Thurston,Castes and Tribes of Southern India

[19] The letters of D.C. of Shimoga and D.C. of Chikmagalur

[20] WP 11894/1985, WP 76/2003 both in Supreme Court

[21] Supreme Court Order for liberty to assail, 2013

[22] L.K.A.Iyer, Vol.I, Chap. VI, page.218-219

[23] A.Dubois, A description of the character, Manners and Customs of the people of India and their Institution and Religious and Civil

[24] C.Valikar,http://www.classicalkannada.org/DataBase/KannwordHTMLS/CLASSICAL\%

20KANNADA\%20RELIGION\%20HTML/TRIBAL\%20RELIGION\%20IN\%20KAR NATAKA.htm

[25] Standing Committee on Social Justice and Empowerment (2011-2012; Fifteenth Lok Sabha),Ministry of Tribal Affairs, The constitution (Scheduled Tribes) order (Second Amendment) Bill, 2011, Twenty third report)

[26] Examples of ST/SC communities that do not fit into the hard and fast definitions:

(1) CHAPTER IV MALAI ARAYANS OF KERALA: A DISTINCT SOCIAL CATEGORY:Prepared by Beehive Digital Concepts

Cochin for Mahatma Gandhi University, Kottayam

(2) http://aptribes.gov.inlbsethno.html

(3)KOCH RAJBANSHI AND KAMTAPURI-THE TRUTH UNVEILED by Ray, N.R.

(4) http://en.wiki pedia.org/wiki/Toda people

(5)According to Insertions/Deletions Polymorphism in Tribal Populations of Southern

Implications, Human Biology. Vol.75. \# 6 December 2003 by Vishwanathan, H., et al.

(6) The Gonds of Vidarbha- Chandrapur District Gazetteer, Maharashtra, also by Deogaonkar,S.G.

(7) An Atlas of Tribal India by M. Raza, A. Ahmad

(8) http://online.assam.gov.in/tribes

(9) Agrawal, A., The Contributions To Indian Sociology(n.s) 38, 1\&2 (2004), SAGE publications, The Bedias are Rajputs': Caste consciousness of a marginal community',

(10) http://www.devendrakulam.org/

(11) Ethnographic Atlas of Indian Tribes by Dr.Bindu Ramachandran, edited by P.C.Mehta 
[27] Minutes of 29th Meeting of NCSC Held on 03.12.2012 at $1: 30$ p.m. Item No.2.15 Agenda Item No. 29.17: Inclusion 'Dhangar in place of'Dhangad', http://www.dhangar.org/

[28] Yakshagana, http://en.wikipedia.org/wiki/Exotic_tribes_of_ancient_India

[29] L.K.A.Iyer, Vol.IV, p.185-186

[30] L.K.A.Iyer, Vol.I, Chapter VI, page 219

[31] http://www.tuluworld.org/dictionary/cgi-bin/web/frame.html

[32] L.K.A.Iyer, Vol.III, page-296-307-Mysore Tribes and Castes on HASĀLAR

[33] Letter by KDSS, MLA, MANDAL, TALUK BOARD

[34] Supreme Court ruling on the spelling of caste and tribes

[35] Government order dated.11 ${ }^{\text {th }}$ March, 2002

[36] Mr.K.L.Negi, Principal Secretary to the Government, Social welfare Department, Govt of Karnataka letter dated.05th January 2005 and letter dated.10th February 2005

[37] Karnataka Rural Water Supply and Environmental Sanitation ProjectII

(http://www.wds.worldbank.orgiservlet/WDSContentServer/IW3P/IB/2002/05/04/000094946_020

11636/Rendered/PDF/multiOpage.pdt 